\title{
The Baseline Bar
}

\author{
Nadia B. Ahmad*
}

\section{INTRODUCTION}

"It is horrifying that we have to fight our own Government to save our environment."

\section{Ansel Adams ${ }^{1}$}

The road to sustainability for the planet's people and natural ecosystems does not include rampant extractivism. ${ }^{2}$ A recent study suggests that more than 80 percent of the world's known hydrocarbon reserves must remain in the ground to avoid runaway climate change. ${ }^{3}$

* Assistant Professor of Law, Barry University Dwayne O. Andreas School of Law; B.A., University of California, Berkeley; J.D., University of Florida Fredric G. Levin College of Law; LL.M. in Natural Resources and Environmental Law and Policy, University of Denver Sturm College of Law. This article has benefited from feedback at the Sabin Colloquium on Innovative Environmental Law Scholarship at Columbia Law School; Southeastern Association of Law Schools Conference in Amelia Island, Florida; Vermont Environmental Law Colloquium at Vermont Law School; Junior Environmental Law Scholars Workshop at the University of Washington School of Law; Institute for Global Law and Policy Conference at Harvard Law School; the annual meeting of the Association of Law, Property, and Society at the University of Georgia School of Law; Faculty Colloquium at Elisabeth Haub School of Law at Pace University; Third World Approaches to International Law Conference at the American University in Cairo; Southeast-Southwest People of Color Conference at Florida A\&M College of Law; and the Sharing Scholarship and Building Teachers Conference at Albany Law School. Special thanks to Barry University Dwayne O. Andreas School of Law and my dean, Leticia Diaz, for the creative space and intellectual support to facilitate this research, and to Kevin Leske, Judith Koons, Marsha Freeman, Glen-Peter Ahlers, Leonard Birdsong, Benjamin Edwards, Cathren Page, Rachel Deming, Brian Sites, Don Smith, Jason Czarnezki, Bridget Crawford, Gina Warren, Blake Hudson, Hari Osofsky, Fred Cheever, Mark Summers, Frank Schiavo, Diana Botluck, Roberta Studwell, Whitney Curtis, and Louis Rosen for feedback and discussion on this work. Thanks to Dillon Andreassi and Andrew Abreu for their research assistance. A note of gratitude to Akmal, Senan, Hanan, my parents, and my siblings. The article's title is inspired by the various "Baseline Bar" restaurants, but the article has no affiliation with or sponsorship from them.

1. Victoria Sheff \& David Sheff, Playboy Interview: Ansel Adams, Playboy, May 1983, at 67, 86 (quoting Ansel Adams).

2. See James Rothwell et al., Paris Climate Change Deal-Ministers Adopt Historic Agreement to Keep Global Warming “Well Below” 2C, TELEGRAPH (Dec. 12, 2015), http://www.telegraph.co.uk/news/earth/paris-climate-change-conference/12047133/Final-text-ofclimate-deal-to-be-released-imminently.html.

3. Christophe McGlade \& Paul Ekins, The Geographical Distribution of Fossil Fuels Unused When Limiting Global Warming to $2^{\circ} \mathrm{C}, 517$ NATURE 187, 187-90 (2015), 
This article challenges the dominant paradigm as to why the "no action" alternative provision of the National Environmental Policy Act (NEPA) is used more as a tool of assessment to move a project forward than instead as a tool of prohibition to halt a project and its deleterious environmental impacts. ${ }^{4}$ To strengthen the "no action" alternative, this article recommends a more detailed analysis to conserve delicate environmental spaces and alleviate the phenomenon of environmental racism. Increased detail and specificity would establish what I refer to as "the baseline bar," the point at which environmental, social, and economic metrics for a proposed federal agency action lead to a recommendation of "no action." The baseline bar can be achieved through NEPA's "no action" alternative as well as through other environmental laws, including the Clean Water Act, the Clean Air Act, the Endangered Species Act, inter alia. The baseline bar would operate to halt project development once specific metrics are not satisfied or delay them so they become economically unfeasible. Manifestations of the baseline bar have led up to the earlier rejection of extractive industry projects, such as Alaska's Pebble Mine and TransCanada's Keystone XL Pipeline. Yet these projects and many other hydrocarbon and mining enterprises now face rebirth. ${ }^{5}$ Adherence to NEPA's procedural requirements could delay or inhibit such projects. The lack of a baseline bar is evident in the water crisis in Flint, Michigan, and the armed standoff over grazing rights in Oregon. Further, this analysis of the baseline bar will work toward understanding the next wave of environmental lawsuits and dispute resolution.

A baseline bar is vital on account of the conspicuous deficiency of updated environmental regulations. New environmental laws have not been enacted since a flurry of activism spawned the passage of numerous environmental laws in the 1970s and early 1980s. This understanding of environmental activities is reflected in NEPA. Comprehensive

\footnotetext{
http://www.nature.com/nature/journal/v517/n7533/pdf/nature14016.pdf. In 2014, the hydrocarbons from public lands included 706 million barrels of crude oil, 3.8 trillion cubic feet of natural gas and 421 million short tons of coal, amounting to billions of tons worth of carbon pollution. U.S. ENERGY INFO. Admin., SALES OF Fossil Fuels Produced FROM FEDERAL AND INDIAN LANDS, FY 2003 $\begin{array}{llllll}\text { THROUGH } & \text { FY } & 2014 & 19-20, & 22 & \text { (July }\end{array}$ http://www.eia.gov/analysis/requests/federallands/pdf/eia-federallandsales.pdf.

4. See 40 C.F.R. $§ 1502.14(d)$ (2016). See generally Lance N. McCold \& James W. Saulsbury, Defining the No-Action Alternative for National Environmental Policy Act Analyses of Continuing Actions, 18 ENVTL. IMPACT ASSESSMENT REV. 15 (1998), http://www.sciencedirect.com/science/article/pii/S0195925597000620.

5. Andrew O'Reilly, Trump's Energy Plans Look to Roll Back Obama's Climate Moves, Fox News (Nov. 21, 2016), http://www.foxnews.com/politics/2016/11/21/trumps-energy-plans-look-toroll-back-obamas-climate-moves.html.
} 
environmental laws sought to regulate commercial activity to harmonize with nature. "When stakeholders and constituencies realized the environmental harms of commercial activity, they sought to protect natural resources and enact environmental laws and regulations." ${ }^{, 7}$ The United States was a party to the 2015 climate change accord in Paris. ${ }^{8}$ Meanwhile, the federal government continues to lease public lands and water for fossil fuel extraction. ${ }^{9}$ The administration of President Donald Trump has sought to deconstruct public land management policies to encourage a national energy plan promoting hydrocarbon extraction activities and reforms to reduce the amount of land managed by the federal government through mechanisms for land transfers to individual states. ${ }^{10}$ In the face of such seismic policy shifts in energy infrastructure projects, NEPA regulations carry a greater burden for protecting environmental systems.

What is unsettling about NEPA is that it does not impose an independent requirement for the federal agency to set a "legal" environmental baseline. The establishment of a "baseline is not an independent legal requirement, but rather, a practical requirement in environmental analysis often employed to identify the environmental consequences of a proposed agency action."11 Consider the baseline bar

6. Nadia B. Ahmad, Meta-Regulation for Environmental Monitoring and Corporate Sustainability Reporting, in CORPORATE RESPONSIBILITY AND SUSTAINABLE DEVELOPMENT: EXPLORING THE NeXUS OF PRIVATE AND PubliC InTEReSTS 177, 179 (Lez Rayman-Bacchus \& Philip R. Walsh eds., 2015).

7. Id.

8. Jess Shankleman, Trump's Fate Will Help Decide Success of Global Pollution Fight, BLOOMBERG (Nov. 7, 2016, 2:00 AM), http://www.bloomberg.com/news/articles/2016-1107/trump-s-fate-will-help-decide-success-of-global-pollution-fight. The Paris climate change deal had 197 countries agree in 2015 to work to reduce global warming to below two degrees Celsius (3.6 degrees Fahrenheit) and seek net zero greenhouse gas emissions. Id. The agreement came into force following ratification by almost 100 countries, including the United States. Id.

9. Ari Phillips, Why the Feds Won't Let You Keep Fossil Fuels in the Ground, MotHER JONES (Oct. 25, 2016, 5:00 AM), http://www.motherjones.com/environment/2016/10/oil-gas-blmclimate-change-lease. The Bureau of Land Management prioritizes hydrocarbon companies when administering leases of 264 million acres of public lands. Id. Terry Tempest Williams and her husband, Brooke, purchased leasing rights to public lands in Utah to deter hydrocarbon extraction, even incorporating a company, Tempest Exploration Co., LLC. Id. BLM ruled that only businesses intending to extract resources from the land could bid. Id. In an interview with Democracy Now!, Tempest Williams said that "lands go up for lease auction, that gives the highest bidder the opportunity to speculate, to drill for oil and make an enormous profit." Id. Tempest Williams said the process "turns public lands into something not public at all, but rather makes them available to the highest bidder from a 'secret society for oil and gas companies." Id.

10. Bobby Magill, U.S. Public Lands Open for Oil Development?, KQED SCI. (Nov. 29, 2016), https://ww2.kqed.org/science/2016/11/29/u-s-public-lands-open-for-oil-development/.

11. Am. Rivers v. Fed. Energy Regulatory Comm'n, 201 F.3d 1186, 1195 n.15 (9th Cir. 2000). 
through the lens of trade and economics. As a starting point, the baseline bar is the status quo to maintain the existing environmental equilibrium. The lack of legal baseline leaves only undefined environmental, social, and economic metrics that lead to a degree of uncertainty, unreliability, and inconclusiveness. This article explores how the separate baseline benchmark bars - social, environmental, and economic - are necessary for establishing and maintaining equilibrium both for trade and environmental protection. As such, considering the "no action" alternative as a baseline bar is the unrelenting ambition for species survival as well as air, water, and soil quality controls. The unimpeded extractivist capitalism model has taken a detrimental toll on the natural world. The baseline bar would be an affirmative negation to unsustainable economic growth in line with the existing NEPA regulations and other environmental mandates. These environmental laws are tools and legal mechanisms to provide protection to life, air, water, and land when economics is a driving motivation. This tussle between nature and commercial activity has been occurring most rapidly since the dawn of the Industrial Revolution. The twenty-first century has yielded new technologies to expand capitalist extractivism to make drilling and mining processes more efficient and increase access to hardto-reach resources. The new technologies have decreased geological barriers for extraction. Increased security forces have lessened political and social impediments. Having a baseline bar to halt projects would force the deployment of renewable energy technologies and require an appreciation for zero-growth economic strategies.

Certain human populations are more vulnerable to environmental degradation, including marginalized communities in low-income areas and people of color. These communities are more likely to be impacted by the disastrous impact of negative environmental externalities. Environmental racism considers how people of color and low-income households are more likely to be in the vicinity of pollution sources and away from clean water, air, and soil. ${ }^{12}$ The location of marginalized communities near sources of pollution springs from racist government policies. ${ }^{13}$ Environmental racism does not capture the environmental

12. Bryce Covert, Race Best Predicts Whether You Live Near Pollution, NATION (Feb. 18, 2016), http://www.thenation.com/article/race-best-predicts-whether-you-live-near-pollution/; Lisa Song, At Flint Debate, Clinton and Sanders Avoid Talk of Environmental Racism, InSIDECLIMATE NEwS (Mar. 8, 2016), http://insideclimatenews.org/news/08032016/environmental-justice-racismflint-water-crisis-hillary-clinton-bernie-sanders-debate-climate-change.

13. Covert, supra note 12. The President and CEO of the National Association for the Advancement of Colored People (NAACP), Cornell Brooks, tweeted regarding the Flint water crisis: "Environmental Racism + Indifference $=$ Lead in the Water \& Blood...." Cornell Brooks 
inequalities created on the basis of class. The term "environmental injustice" more adequately accounts for the marginalization of communities on the basis of class as well as race. ${ }^{14}$

The absence of a legal environmental baseline limits incentives for industry operators to adequately account for environmental inequalities in the environmental impact statement process. The United States provides a government mechanism for the formation of environmental impact assessment reports. ${ }^{15}$ These environmental problems present a legal predicament. What is problematic of the environmental impact statement process is the lack of standardization in these regulations. While the implementation of a legal baseline may be more difficult to achieve, I additionally propose a more robust analysis of the "no action" alternative. This more robust analysis of the "no action" alternative would be in line with previous Council of Environmental Quality (CEQ) guidelines. ${ }^{16}$ Changes in White House leadership in 2017 have led to lower prioritization of previous efforts at climate change adaptation and consideration of environmental justice impacts. As such, a deeper analysis of the "no action" alternative can provide environmental and land conservation activists additional NEPA claims to legally contest extraction projects. The "no action" alternative is not an indication "nothing happens." 17 For example, the "no action" alternative can "continue to implement the management direction in the land use plan"

(@CornellWBrooks), TwitTer (Jan. 24, 2016, 11:01 AM), https://twitter.com/CornellWBrooks/status/691334918299844608. In the 1930s, officials from federal housing agencies redlined black neighborhoods, creating situations that trapped black people into crowded city centers, allowing whites to retreat to the suburbs. Covert, supra note 12. During this same period of the 1930s, maps in Flint showed black neighborhoods colored in red. Id. Redlining worsened poverty in predominately black neighborhoods as residents had restricted access to wealth accumulation accessed through affordable home loans available to whites. Id.

14. LuKe W. Cole \& Sheila R. Foster, From the Ground Up: EnVironmental Racism AND THE RISE OF THE ENVIRONMENTAL JUSTICE MOVEMENT 15-17 (2000).

15. Robert D. Bullard \& Glenn S. Johnson, Environmental Justice: Grassroots Activism and Its Impact on Public Policy Decision Making, 56 J. Soc. Issues 555, 561 (2000), https://www.researchgate.net/profile/Glenn_Johnson5/publication/227505470_Environmental_Justic e_Grassroots_Activism_and_Its_Impact_on_Public_Policy_Decision_Making/links/004635301af2fa a16b000000.pdf.

16. Christina Goldfuss, COUNCIL ON Envtl. Quality, Final Guidance FOR Federal

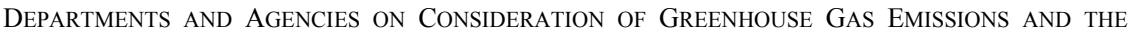
Effects of Climate Change in National Environmental Policy Act Reviews (Aug. 1, 2016),

https://www.whitehouse.gov/sites/whitehouse.gov/files/documents/nepa final ghg guidance.pdf.

17. Examples of No Action Alternatives, Bureau LAND MGMT. (July 29, 2010), https://www.blm.gov/wo/st/en/prog/planning/nepa/webguide/document_pages/examples_of_no_acti on.html. 
as it already occurs. ${ }^{18}$ Another example could be that the "no action" alternative could, in fact, be not to take action and generally "reject the proposal or deny the application." 19

In analyzing the impact of climate change and increasing infrastructure development of hydrocarbon resources and other extractive industries, the unsustainability of these enterprises cannot be overstated. This intense level of development can be counteracted with zero-growth strategies. With increased energy consumption, soaring population growth, and more intense land use impacts, a more robust "no action" alternative is a key in the analysis for considering the environmental impact statement on whether or not the project should go forward. This article will proceed in three parts. Part II will provide an overview of the environmental impact statement processes and problematize the lack of uniformity embedded in these processes. ${ }^{20}$ Part III will suggest ways of incorporating this proposal for a baseline bar to create more robust environmental impact statements through case studies and legal decisions. $^{21}$ This section will analyze the unique dimensions of environmental, social, and economic metrics for the assessment process. $^{22}$ Part IV will reconcile the "no action" alternative with existing laws and illustrate the normative implications of the baseline bar and the more robust analysis of the "no action" alternative. ${ }^{23}$

\section{UNDERSTANDING IMPACT STATEMENTS}

"ГTlo waste, to destroy, our natural resources, to skin and exhaust the land instead of using it so as to increase its usefulness, will result in undermining in the days of our children the very prosperity which we ought by right to hand down to them amplified and developed."

Theodore Roosevelt ${ }^{24}$

Seeing the importance of the natural ecosystem as a factor in economic development was a departure from earlier discussions of development. $^{25}$ This shift in understanding led to the realization that

\footnotetext{
18. Id.

19. Id.

20. Infra Part II.

21. Infra Part III.

22. Id.

23. Infra Part IV.

24. President Theodore Roosevelt, Seventh Annual Message to Congress (Dec. 3, 1907), http://www.presidency.ucsb.edu/ws/?pid=29548.

25. Ahmad, supra note 6, at 178 .
} 
development "would have to be conducted with a degree of consideration for the natural world." 26 The rulemaking that led up to the impact statement mandate suggests a "continuing policy" of federal, state, and local governments in coordination with public and private actors "to use all practicable means and measures ... in a manner calculated to foster and promote the general welfare...."27 The underlying impact statement strategy was to develop a system by which the human and the natural worlds could co-exist and satisfy societal and economic needs for current and future generations. This strategy mimicked the international call for sustainable development, as defined in Our Common Future, also known as the Brundtland Report, ${ }^{28}$ which asked for "development that meets the needs of the present without compromising the ability of future generations to meet their own needs." 29

NEPA, which was signed into law on January 1, 1970, required federal agencies to calculate the environmental effects of their proposed actions before issuing a decision. ${ }^{30}$ The range of actions covered by NEPA is broad and covers permit applications, federal land management actions, and highways and other publicly-owned facilities. ${ }^{31}$ Using the NEPA process, agencies evaluate the environmental and related social and economic effects of their proposed actions. ${ }^{32}$ Agencies offer means for public review and comment on those evaluations.

\footnotetext{
26. Id.

27. Serge Taylor, Making Bureaucracies Think: The Environmental Impact Statement StRategy of AdMinistrative Reform 33 (1984) (quoting 42 U.S.C. § 4331(a) (1970)).

28. Ahmad, supra note 6, at 179.

29. WORLD COMM'N ON ENV'T \& DEV., REPORT OF THE WORLD COMMISSION ON ENVIRONMENT AND DEVELOPMENT: OUR COMMON FUTURE 9, 41 (1987), http://www.undocuments.net/our-common-future.pdf. The United Nations Conference on the Human Environment in Stockholm, in 1972, "represented a first taking stock of the global human impact on the environment, an attempt at forging a basic common outlook on how to address the challenge of preserving and enhancing the human environment." Günther Handl, Introductory Note, UNITED NATIONS, http://legal.un.org/avl/ha/dunche/dunche.html (last visited Jan. 21, 2017). The Stockholm Declaration contained broad policy goals and concerned "the need for a common outlook and for common principles to inspire and guide the peoples of the world in the preservation and enhancement of the human environment." UNITED NATIONS ENV'T PROGRAMME, Declaration of the United Nations Conference on the Human Environment, UNEP, http://www.unep.org/documents.multilingual/default.asp?documentid=97\&articleid=1503 (last visited Jan. 21, 2017) (listing the proclamation made on June 16, 1972). Post-Stockholm, "global awareness of environmental issues increased dramatically, as did international environmental lawmaking proper." Handl, supra.
30. 42 U.S.C. $\$ 4332$ (2012)
31. See id. $\$ 4321$.
32. See id. $\S 4332$. 


\section{A. Environmental Impact Statement as a Procedural Mechanism}

In the social sciences and business, benchmarking provides a point of data comparison through results, inputs, and measurements for data analysis and reporting. "Some authors have used definitions such as 'Measuring an operation's or departments' performance compared to others'... or 'The establishment of operating targets based on best practices." 34 In the realm of environmental law, benchmarking also occurs in the preparation of impact statements which assess the feasibility of a project. I argue that more environmental data should be generated and used in making agency determinations. Information is power. More so, access to information is power. Sidney Shapiro and Rena Steinzor proposed a plan for establishing positive metrics that could offer a valuable tool to promote agency accountability. ${ }^{35}$ Alyson Flournoy suggested that metrics could serve as shorthand for determining the quality and quantity of natural resources in her proposal for a new statute - the National Environmental Legacy Act- "to define in concrete terms the environmental legacy we wish to leave to future generations and provide a mechanism to ensure that we preserve that legacy." ${ }^{36}$ I propose that having a more precise measure of water quality, air quality, soil impacts, and climate change impacts in the "no action" alternative of NEPA would provide a clearer rendition of the actual "big picture" of a project. Doing so would enable marginalized groups, environmental activists, and communities collectively to have improved administrative regimes and increased access to information. Vigorous argument exists over the nature of the state's obligations to future generations. ${ }^{37}$

NEPA's federal mandate includes statutory responsibilities of "fulfill[ing] the responsibilities of each generation as trustee of the environment for succeeding generations," "assur[ing] for all Americans safe, healthful, productive, and esthetically and culturally pleasing

33. Martin Carroll, Benchmarking in the New Zealand Tertiary Education Sector, in Benchmarking: Theory and Practice 1, 2 (Robyn Harris ed., 2001). See also Leeanne Pitman, Isabella Trahn \& Anne Wilson, Working Towards Best Practice in Australian University Libraries: Reflections of a National Project, in BENCHMARKING: THEORY AND PRACTICE 19, 19 (Robyn Harris ed., 2001).

34. Carroll, supra note 33, at 2 (citations omitted).

35. Sidney A. Shapiro \& Rena Steinzor, Capture, Accountability, and Regulatory Metrics, 86 TEX. L. REV. 1741, 1769-71 (2008).

36. Alyson C. Flournoy, The Case for the National Environmental Legacy Act, in BEYOND Environmental Law: Policy Proposals for a Better Environmental Future 3, 4 (Alyson C. Flournoy \& David M. Driesen eds., 2010).

37. See generally Obligations to Future Generations (R.I. Sikora \& Brian Barry eds., 1978). 
surroundings," and "attain[ing] the widest range of beneficial uses of the environment without degradation, risk to health or safety, or other undesirable and unintended consequences. ${ }^{38}$ The rules also state specifically an assurance of safe and healthy surroundings for all Americans. ${ }^{39}$ Since NEPA litigation has been ongoing since the statute was passed in 1969, most questions about the Act's requirements might seem to have been settled. ${ }^{40}$ Expanded federal activity, complex systems, and higher public awareness of NEPA's mandates have increased the importance of NEPA's procedural requirements. Other legal scholars have looked at "the proof necessary to sustain a legal challenge to a federal agency's failure" of compliance with the actual preparation of an impact statement, or "allegations that a statement issued by the agency did not adequately assess the proposed action's environmental impacts." 41 The Forest Chief "identified four "primary deficiencies' in [the] prior forest plan, and none of those deficiencies" considered cessation or any other serious deviations to livestock grazing. ${ }^{42}$

The Supreme Court recognized that NEPA articulates "a broad national commitment to protecting and promoting environmental quality."43 After NEPA's passage, the House congressional committee with jurisdiction over NEPA described the law "as revolutionary in intent and designed to steer this Nation on a course of environmental management." 44 Since then, "NEPA has spurred countless lawsuits, put innumerable lawyers and consultants to work, and, by most accounts,

38. Mason Baker, Note, What Does It Mean to Comply with NEPA?: An Investigation into Whether NEPA Should Have Procedural or Substantive Force, 31 UtAH EnVTL. L. ReV. 241, 247 (2011) (quoting 42 U.S.C. $§ 4331$ (2000)).

39. 42 U.S.C. $\$ 4331(b)(2)(2012)$.

40. Baker, supra note 38, at 241.

41. Ray Vaughan, Necessity and Sufficiency of Environmental Impact Statements Under the National Environmental Policy Act, 38 AM. Juris. Proof OF FACTS 3d 547, $§ 1$ (1996). The "United States Forest Service (USFS) met rule or reason" relating to its "choice of alternatives in its final environmental impact statement" regarding the "proposed amendment to forest plan for Black Hills National Forest, and, specifically, its omission of no grazing alternative was not arbitrary or capricious." Id. at $\S 6$.

42. Id. "USFS then considered two no action and four action alternatives," which addressed livestock, but "changing forest-wide grazing was not major purpose of proposed amendments." Id. See 42 U.S.C. $\S 4332$ (C)(iii) (2012).

43. Robertson v. Methow Valley Citizens Council, 490 U.S. 332, 348 (1989) (citing 42 U.S.C. $\S 4331)$.

44. Sam Kalen, The Devolution of NEPA: How the APA Transformed the Nation's Environmental Policy, 33 WM. \& MARY ENVTL. L. \& POL'Y REV. 483, 484 (2009) (citing COMM. on Merch. Marine \& Fisheries, Administration of the National EnVironmental Policy ACT, H.R. REP. 92-316, at 1 (1971)). 
produced a much more environmentally informed federal bureaucracy." ${ }^{45}$ Legal scholars have argued that despite the procedural pitfalls, NEPA remains relevant and "has the potential to be used as a powerful tool to help orient our government, and even society, towards the goal of sustainability."46

NEPA "requires federal agencies to incorporate environmental considerations in their planning and decision-making through a systematic interdisciplinary approach." ${ }^{, 47}$ "[D]etailed statements assessing the environmental impact of and alternatives to major federal actions significantly affecting the environment" are required by NEPA, and known as the Environmental Impact Statements (EIS) and Environmental Assessments (EA). ${ }^{48}$ Under NEPA, a detailed statement as to the environmental impact of a revised federal agency action significantly affecting quality of the human environment must be prepared. ${ }^{49}$ An agency finding that no EIS need be prepared is termed a "Finding Of No Significant Impact" (FONSI) by the relevant regulations. ${ }^{50}$

The detailed EIS must describe (i) "the environmental impacts of the alternatives including the proposed action," (ii) "any adverse effects that cannot be avoided should the proposed action be implemented," (iii) "the relationship between short-term uses of the environment and the maintenance and enhancement of long-term productivity," and (iv) "any irreversible or irretrievable commitments of resources which would be involved in the proposal should it be implemented."51 In interpreting NEPA, the Council on Environmental Quality (CEQ) crafted regulations to insure "environmental information is available to public officials and citizens before decisions are made and before actions are taken." Various provisions demonstrate that NEPA seeks to create an open and collaborative process. ${ }^{53}$

45. Id. See generally Frederick R. ANDERSON, NEPA IN THE Courts: A Legal ANALYSIS of the National EnVironmental Policy ACt (1973); Richard J. LAZARUS, THE MaKing of ENVIRONMENTAL LAW (2004).

46. Kalen, supra note 44, at 548.

47. What Is the National Environmental Policy Act?, EPA, https://www.epa.gov/nepa/whatnational-environmental-policy-act (last visited Jan. 21, 2017).

48. Id.

49. 42 U.S.C. § 4331 (2012). See also Nadia B. Ahmad, Necessity and Sufficiency of Environmental Impact Statements Under \$ 102(2)(c) of National Environmental Policy Act of 1969 (42 U.S.C.A. $\$ 4332(2)(c))$ Concerning Climate Change, 85 A.L.R. FED. 2D 1 (2014).

50. Ahmad, supra note 49 , at 2 .

51. 22 C.F.R. $\S 216.6(\mathrm{c})(5)(2016)$

52. 40 C.F.R. $\S 1500.1(b)(2016)$.

53. 40 C.F.R. $§ 1501.6$ (2016) ("emphasiz[ing] agency cooperation early in the NEPA 
In Colorado Environmental Coalition v. Salazar, environmental groups claimed that the Bureau of Land Management (BLM) failed to satisfy NEPA's procedural mandates. ${ }^{54}$ The plan allowed all public land within the Roan Plateau Planning Area to be available for leasing to private oil and gas entities. ${ }^{55}$ The district court ruled that BLM violated NEPA by inadequately considering cumulative air quality effects. ${ }^{56}$ On remand, the court did not offer the agency any instructions in curing the procedural deficiency. ${ }^{57}$ "The court's lack of guidance on remand is consistent with the Tenth Circuit's refusal to equate NEPA's procedural requirements with the production of hard data." 58 This deficiency in the requirement to produce hard data or a scientific benchmark shows why a baseline bar can make NEPA an even more powerful tool. The baseline bar would offer social, environmental, and economic metrics to more fully evaluate a resource plan as well as other projects. Some may argue this higher benchmark imposes an undue burden on federal agencies. ${ }^{59}$ NEPA's underlying policies of public awareness and informed decisionmaking cannot be achieved without objective measurements and analysis of social, environmental, and economic data with scientific backing. Not having this information included in the EIS makes decision-making more subjective and more likely to yield in favor of economic interests.

process" and providing a mechanism for "cooperating agencies"); 40 C.F.R. $\S 1501.7$ (2016) (requiring "an early and open process for determining the scope of issues to be addressed and for identifying the significant issues related to a proposed action"); 40 C.F.R. $\S 1502.19$ (2016) (requiring circulation of draft and final environmental impact statements).

54. 875 F. Supp. 2d 1233, 1243 (D. Colo. 2012). See also Sean Patrick Farrell, Defending the Not-Quite-Wild, N.Y. TIMES, Oct. 30, 2009, at B1; Anthony Licata, An Overview of the Roan Plateau, FIELD \& STREAM (July 20, 2010), http://fieldandstream.com/blogs/finding-deerhunt/2010/07/overview-roan-plateau; Roan Plateau, LANDSCOPE AMERICA, http://www.landscope.org/colorado/places/Roan\%20Plateau (last visited Jan. 21, 2017).

55. Colo. Envtl. Coal., 875 F. Supp. 2d at 1239-40.

56. Id. at 1256 .

57. See id.

58. William Griffin, Comment, NEPA and the Roan Plateau: Forcing the Bureau of Land Management to Take a Hard Look, 40 B.C. ENVTL. AFF. L. REV. 553 (2013) (quoting text from the abstract of the article).

59. See id. at 555. 


\section{B. The NEPA Mandate as Action Forcing}

"The earth will not continue to offer its harvest, except with faithful stewardship. We cannot say we love the land and then take steps to destroy it for use by future generations."

Pope John Paul II, Mass for the Rural Workers ${ }^{60}$

The action-forcing procedural requirements are necessary for NEPA compliance. Those factors are the environmental impact, adverse environmental effects, and the alternatives to the proposed action. NEPA requires that a wide range of environmental effects ${ }^{61}$ be evaluated under 40 C.F.R. $§ 1502.16$, including: direct effects - effects that "are caused by the action and occur at the same time and place"; 62 indirect effectseffects that "are caused by the action and are later in time or farther removed in distance, but are still reasonably foreseeable"; ${ }^{33}$ cumulative impacts - "the impact on the environment which results from the incremental impact of the action when added to other past, present, and reasonably foreseeable future actions regardless of what agency (federal or non-federal) or person undertakes such other actions."64 Executive power causes agency action to "make achieving environmental justice part of its mission by identifying and addressing, as appropriate, disproportionately high and adverse human health or environmental effects of its programs, policies, and activities on minority populations and low-income populations in the United States and its territories." ${ }^{\circ 5}$ The EPA has this goal for all communities and people across the

60. Pope John Paul II, Mass for the Rural Workers at Laguna Seca, Monterey Peninsula (Sept. ii_hom_19870917_messa-agricoltori.html.

61. Effects, whether direct, indirect, or cumulative, fall into various topical categories. 40 C.F.R. $\S 1508.8$ (2016).

62. Id. $\S 1508.8(\mathrm{a})$

63. Id. $\S 1508.8(\mathrm{~b})$.

64. Id. $\S 1508.7$. "Cumulative impacts can result from individually minor but collectively significant actions taking place over a period of time." Id.

65. Exec. Order No. 12,898, 59 Fed. Reg. 7629, 1-101 (Feb. 11, 1994). The report Toxic Wastes and Race at Twenty: 1987-2007: Grassroots Struggles to Dismantle Environmental Racism in the United States - a report prepared for the United Church of Christ Justice and Witness Ministries - defined environmental justice "as the "fair treatment and meaningful involvement of all people regardless of race, color, national origin or income with respect to the development, implementation and enforcement of environmental laws, regulations and policies." ROBERT D. Bullard ET. AL., TOXIC WASTES AND RACE AT TWENTY: 1987-2007: GRASSROOTS STRUGGLES TO Dismantle ENVIRONMENTAL RACISM IN THE UNITED STATES 2 (March 2007), http://www.ejnet.org/ej/twart.pdf. 
country. ${ }^{66}$ Actualizing environmental justice would lead to the same protections from environmental and health hazards for all people and access to the decision-making process to have a healthy environment. ${ }^{67}$

The National Resources Defense Council indicates that the poor, rural, and predominantly African-American community in Warren County, North Carolina, was the birthplace of the environmental justice movement. ${ }^{68}$ The state government designated Warren County as a hazardous disposal site for 6,000 truckloads of soil laced with toxic polychlorinated biphenyl known as $\mathrm{PCBs},{ }^{69}$ which are carcinogenic and may lead to neurotoxicity. ${ }^{70}$

President John F. Kennedy, who was a proponent of environmental justice, said, "[s]imple justice requires that public funds, to which all taxpayers of all races contribute, not be spent in any fashion which encourages, entrenches, subsidizes or results in racial discrimination." ${ }^{, 71}$ In 1994, an Executive Order by then President Clinton was issued to direct federal agencies to incorporate achieving environmental justice into their mission. ${ }^{72}$ The Presidential Memorandum at the time stated:

66. Learn About Environmental Justice, EPA, https://www.epa.gov/environmentaljustice/learnabout-environmental-justice (last visited Jan. 21, 2017).

67. See id.

68. Renee Skelton \& Vernice Miller, The Environmental Justice Movement, NAT'L RESOURCES Def. COUNCIL (Mar. 17, 2016), https://www.nrdc.org/stories/environmental-justicemovement.

69. Id. Warren County's protest captured national attention on environmental injustice and the resulting environmental racism:

The dump trucks first rolled into Warren County in mid-September, 1982, headed for a newly constructed hazardous waste landfill in the small community of Afton. But many frustrated residents and their allies, furious that state officials had dismissed concerns over PCBs leaching into drinking water supplies, met the trucks. And they stopped them, lying down on roads leading into the landfill. Six weeks of marches and nonviolent street protests followed, and more than 500 people were arrested-the first arrests in U.S. history over the siting of a landfill.

The people of Warren County ultimately lost the battle; the toxic waste was eventually deposited in that landfill. But their story-one of ordinary people driven to desperate measures to protect their homes from a toxic assault- drew national media attention and fired the imagination of people across the country who had lived through similar injustice. The street protests and legal challenges mounted by the people of Warren County to fight the landfill are considered by many to be the first major milestone in the national movement for environmental justice.

Id.

70. See Susan L. Schantz, Developmental Neurotoxicity of PCBs in Humans: What Do We Know and Where Do We Go From Here?, 18 Neurotoxicology \& Teratology 217, 218 (1996).

71. President John F. Kennedy, Special Message to the Congress on Civil Rights and Job Opportunities (June 19, 1963), http://www.presidency.ucsb.edu/ws/?pid=9283.

72. Exec. Order No. 12,898, 59 Fed. Reg. 7629 (Feb. 11, 1994). 
In accordance with Title VI of the Civil Rights Act of 1964, each Federal agency shall ensure that all programs or activities receiving Federal financial assistance that affect human health or the environment do not directly, or through contractual or other arrangements, use criteria, methods, or practices that discriminate on the basis of race, color, or national origin.

The rise of environmental pollution and disparate impacts on communities of color and low-income households has not kept pace with laws for better environmental protection. In fact, Title VI claims suffer from a backlog in bringing about environmental accountability and administrative agency oversight.

\section{Full Spectrum of Reasonable Alternatives}

CEQ guidance is vast, but notes that in the case of when "a very large number of alternatives" are present, the federal agency must "only consider a 'reasonable number' but they must cover the full spectrum of alternatives."74 Environmental impact statements need to consider climate change and greenhouse gases in their environmental analysis. ${ }^{75}$ The purpose of requiring a side-by-side comparison of reasonable alternatives is to "sharply defin[e] the issues and provid[e] a clear basis for choice among options by the decisionmaker and the public." "76 As the project purpose is narrowed, the range of alternatives also gets narrowed, often resulting in the rejection of environmental-friendly alternatives. ${ }^{77}$ In light of Department of Transportation v. Public Citizen, ${ }^{78}$ it is important for plaintiffs challenging an EA/EIS to affirmatively propose alternatives ignored by the agency. Failure to make specific recommendations could be fatal to a plaintiff's case. ${ }^{79}$

73. Memorandum from President William Clinton on Exec. Order on Fed. Actions to Address Envtl. Justice in Minority Populations \& Low-Income Populations (Feb. 11, 1994), https://www.epa.gov/sites/production/files/2015-02/documents/clinton_memo_12898.pdf.

74. DANiel R. MANDELKer, NEPA LAW AND Litigation $\bar{\S}$ 10:09[4] (Clark Boardman Callaghan 1992); see also Michelle B. Nowlin, NEPA and Environmental Justice, SN044 ALI-ABA $583,591-92$ (2008) (discussing the analysis of alternatives to proposed actions required by NEPA).

75. See Nowlin, supra note 74 , at 614-15 (explaining that courts have found agencies reviewing environmental impacts need to consider the effects of greenhouse gas emissions and climate change).

76. 40 C.F.R. $\S 1502.14$ (2016).

77. In Simmons v. U.S. Army Corps of Engineers, 120 F.3d 664, 667 (7th Cir. 1997), project proponents wanted to dam a river to create a single water source for two areas, and the Corps "failed to examine the full range of reasonable alternatives" by accepting this desired "single-source" purpose.

78. 541 U.S. 752 (2004)

79. See id. at $764-65$. 


\section{The "No Action" Alternative}

"My world, my Earth, is a ruin. A planet spoiled by the human species. We multiplied and gobbled and fought until there was nothing left, and then we died. We controlled neither appetite nor violence; we did not adapt. We destroyed ourselves. But we destroyed the world first."

Ursula K. Le Guin, The Dispossessed ${ }^{80}$

Section 1502.14(d) of the Code of Federal Regulations provides the mandate for the EIS to "include the alternative of no action." 81 Two interpretations of the "no action" emerge based on the type of proposal. ${ }^{82}$ The first situation would involve updates to a land management plan where present programs initiated under existing legislation and regulations would continue. ${ }^{83}$ The second interpretation of "no action" is based on federal decisions for such projects. ${ }^{84}$ At its core, the "no action" alternative analysis provides a baseline for decision-makers to gauge the environmental impacts of a project. ${ }^{85}$

Courts have rejected insufficient impact statements. Courts have required the federal agency to include data on which it relies on for the environmental analysis, noting that baseline data is crucial to provide a hard look at the proposed infrastructure project. ${ }^{86}$ The U.S. District Court for the District of Oregon indicated "[i]t is against baseline information that environmental impacts are measured and evaluated; therefore, it is critical that the baseline be accurate and complete." ${ }^{\prime 7}$

The CEQ regulations mandate agencies consider the effects of taking "no action" at all. "The no action alternative may be thought of

80. Ursula K. Le Guin, The Dispossessed 306 (1974) (quoting the fictional character Keng's message about a future disaster to Shevek).

81. 40 C.F.R. $\$ 1502.14$ (d) (2016).

82. See George C. Coggins \& Robert L. Glicksman, 2 Public Natural Resources LAW 17-47 (2d ed. 2016).

83. Id. at $17-271$. In these situations, the "no action" alternative is "no change" from the current management direction or level of management intensity. Id. at 17-47 n.2.10.

84. Id. at $17-272$.

85. Id. at 17-271 to 17-272 (citing Biodiversity Conservation All. v. U.S. Forest Serv., 765 F.3d 1264, 1268-70 (10th Cir. 2014)).

86. Cent. Or. Landwatch v. Connaughton, 905 F. Supp. 2d 1192, 1197 (D. Or. 2012).

87. Id. (citation omitted); see also Cent. Sierra Envtl. Res. Ctr. v. U.S. Forest Serv., 916 F. Supp. 2d 1078, 1090-91 (E.D. Cal. 2013) (discussing plaintiff's failure to demonstrate flaws in the definition of the baseline of existing conditions).

88. Native Ecosystems Council v. U.S. Forest Serv., 428 F.3d 1233, 1235, 1245-46 (9th Cir. 2005) (affirming summary judgment relating to the approval of a project proposing thinning, prescribed burning, and weed management and to a no-action alternative to reduce potential for catastrophic fire). 
in terms of continuing with the present course of action until that action is changed." "NE "NEPA does not impose an independent requirement that the agency set a 'legal' environmental baseline." " However, "the discussion of alternatives in an EIS must compare the beneficial and adverse effects of the alternatives considered against a no action status quo alternative. ... Further, the baseline must be consistent throughout the analysis in the EIS."

Part II will address how benchmarks for the baseline bar can be created in line with a more robust analysis of the "no action" alternative. While the same metrics cannot be applied to all situations, certain commercial activities, including mining, fossil fuel extraction, timber harvesting, and pipeline projects should face more scrutiny given the land use impact and potential for toxic waste.

\section{THE BASELINE BAR AS A LEGAL TOOL}

"Understand: the task of an activist is not to negotiate systems of power with as much personal integrity as possible-it's to dismantle those systems."

Lierre Keith, The Vegetarian Myth: Food, Justice, and Sustainability ${ }^{92}$

Historically, the reasonable alternatives, particularly the "no action" alternative, were perceived as essential to the EIS mandate. ${ }^{93}$ While agency personnel were concerned about the number of alternatives required, the alternatives themselves were not fully scrutinized. ${ }^{94}$ Dinah Bear explains the rationale for this growing aversion to alternatives, noting "[o]ne line of thought holds that alternatives simply take too much time and elimination of them will further streamline the environmental review process." 95 The second reason, she explains, is "that requiring alternatives identification and analysis is antithetical to collaboration." At the same time, the courts have pushed back on requirements to limit

\footnotetext{
89. CogGins \& GLiCKSMAN, supra note 82, at 17-271 (internal quotation and citations omitted).

90. Id. at 17-272 (citations omitted).

91. Id. at 17-272 to 17-273 (citations omitted).

92. Lierre Keith, The Vegetarian Myth: Food, Justice, and Sustainability 265 (2009).

93. Dinah Bear, Some Modest Suggestions for Improving Implementation of the National Environmental Policy Act, 43 NAT. ReSOURCES J. 931, 938 (2003).

94. Id.

95. Id. at 939

96. Id.
} 
the number of alternatives and the sufficiency of the detail included in the specific alternatives. The "no action" alternative has specifically been evaluated as discussed in this section.

For example, in the course of evaluating the options that would best satisfy the purpose of the proposed action, the Ninth Circuit indicated that the federal agency "failed to consider an adequate range of alternatives." $" 97$ The court recognized the vagueness and lack of specificity of NEPA's mandate for the "no action" alternative. ${ }^{98}$ The CEQ issued an informatory memorandum on the topic.99 The memorandum provides in pertinent part: "[P]rojected impacts of alternative management schemes would be compared in the EIS to those impacts projected for the existing plan. In this case, alternatives would include management plans of both greater and lesser intensity, especially greater and lesser levels of resource development."100 This analysis offers a benchmark for officials "to compare the magnitude of environmental effects of the action alternatives." 101 In light of expansive infrastructure projects and increasing energy technologies, the need to implement a baseline bar on NEPA actions will be crucial for environmental protection. For example, Gina Warren observed that "[e]nergy distribution systems should be updated with smart grid technology ... to accommodate distributed generation and the flow of electricity...."102 These changes will result in clean energy infrastructure projects that will warrant NEPA review. This section will examine the rulemaking process, litigation efforts, and grassroots activism that led to the halting of the Alaska's Pebble Mine and TransCanada's controversial Keystone XL Pipeline. These cases illustrate how at the federal, state, and local level efforts at environmental sustainability trumped the benefits of increased economic activity. A point occurs where the economics cannot justify the social and environmental costs of a project. This point is what I describe as the baseline bar.

\footnotetext{
97. Muckleshoot Indian Tribe v. U.S. Forest Serv., 177 F.3d 800, 813 (9th Cir. 1999).

98. See id. at 814 (quoting Robertson v. Methow Valley Citizens Council, 490 U.S. 332, 350 (1989)) ("NEPA 'does not mandate particular results,' but 'simply provides the necessary process' to ensure that federal agencies take a 'hard look' at the environmental consequences of their actions.").

99. Forty Most Asked Questions Concerning CEQ's Nat'l Envtl. Policy Act Regulations, 46 Fed. Reg. 18,026 (Mar. 23, 1981) [hereinafter Forty Questions].

100. Id. at 18,027 .

101. Pac. Coast Fed'n of Fishermen's Ass'ns v. U.S. Dep't of the Interior, 929 F. Supp. 2d 1039, 1050-51 (E.D. Cal. 2013) (quoting Forty Questions, supra note 99, at 18,027).

102. Gina S. Warren, Vanishing Power Lines and Emerging Distributed Generation, 4 WAKE FOREST J.L. \& POL'Y 347, 374 (2014).
} 


\section{A. The Environmental Baseline: Analysis of Alaska's Pebble Mine and Water Quality}

"The land is sacred.

These words are at the core of your being.

The land is our mother,

The rivers our blood.

Take our land away and we die.

That is, the Indian in us dies."

Mary Brave Bird ${ }^{103}$

The Pebble Mine Project was "a copper-gold-molybdenum porphyry deposit in the advanced exploration stage" 104 and the second-largest deposit of its kind in the world. ${ }^{105}$ The project is located on state land in the Bristol Bay Region of southwest Alaska. ${ }^{106}$ The project was placed on hold by the Pebble Limited Partnership (PLP) following a federal decision to halt the project. ${ }^{107}$ In the Bristol Bay watershed, the project is at "the headwaters of one of the most productive salmon fisheries in Alaska." 108 Even though "the company claims that development of the mine can be done ... to protect the aquatic ecosystem, that possibility is unlikely."109 This section will examine how legal benchmarks for water quality swayed the decision to stop the extraction project. This failed venture provides an opportunity to show how the establishment of a baseline bar can be used with greater uniformity and specificity for EIS analysis. The ecological and biodiversity concerns of the region were factored into the economic metrics of the impact of the proposed mining project on Alaska's fishing industries. While NEPA review was not completed for the Pebble Mine project, this case illustrates the importance of the baseline bar and the interplay of environmental, social, and economic metrics for analysis.

Sockeye salmon measure 18 to 31 inches in length and weigh 4 to 15

103. Jean Elizabeth Ward, EARTH SPIRIT: NATIVE AMERICAN 23 (2007) (quoting Mary Brave Bird's prose).

104. Pebble Project, ALASKA DEP'T NAT. RESOURCES, http://dnr.alaska.gov/mlw/mining/largemine/pebble/ (last visited Jan. 21, 2017).

105. Elizabeth Bluemink, Pebble's Value Keeps Growing, AlasKa DisPatch News (Feb. 25, 2008), http://www.adn.com/article/20080225/pebbles-value-keeps-growing.

106. Pebble Project, supra note 104.

107. See id.

108. Pebble Project, NORTHERn ALASKA EnVTL. CTR., http://northern.org/programs/cleanwater-mines/hardrock-mines-in-interior-and-arctic-alaska/pebble-project/pebble-project (last updated Mar. 26, 2010).

109. Id. 
pounds and are located in the headwaters near the proposed Pebble Mine. ${ }^{110}$ Through a study, the mining company estimated that the Pebble Mine project could support 15,000 American jobs and contribute more than $\$ 2.4$ billion annually to U.S. GDP over several decades. ${ }^{111}$

An additional concern with the Pebble Mine project was the issue of public participation in the decision-making process. Aside from the Alaska Coastal Management Program and land disposals or leases, the remaining state statutes implemented by the Department of Natural Resources (DNR) or the Alaska Department of Fish \& Game (ADF\&G), which apply to Pebble Mine, do not provide opportunities to offer public notice and comment. ${ }^{112}$ DNR and ADF\&G are dependent on a federal EIS for notice and comment on state permits. ${ }^{113}$ NEPA regulations require the impact statement be coordinated alongside state and local permits. ${ }^{114}$ Consequently, state and local permits are decided at the same time and with the same information as the federal permits. ${ }^{115}$ Democratic and transparent environmental decision-making is lacking on the state level. Meanwhile, on the federal level the call for public comments is noticed during a small window of time, which may not afford opportunity to all who are interested to offer comment.

\section{Clean Water Initiatives and Opposition to Pebble Mine}

Opposition to Pebble Mine began in 2005 with concerns regarding salmon in Bristol Bay. ${ }^{116}$ Following failed attempts at the state level,

110. See Sockeye Salmon (Oncorhynchus nerka), ALASKA DeP'T FiSH \& GAME, http://www.adfg.alaska.gov/index.cfm?adfg=sockeyesalmon.main (last visited Jan. 21, 2017). Sockeye salmon return upriver to their spawning grounds. Id. The largest sockeye salmon populations are in the Kvichak, Naknek, Ugashik, Egegik, and Nushagak Rivers that flow into Alaska's Bristol Bay as well as in the Fraser River system in Canada. Id. Threats include habitat loss and degradation, climate change, and overfishing. $I d$. Otherwise, in good years, the numbers of fish can be in the tens of millions. Id.

111. IHS Global Insight, The ECONOMic AND EMPloyment Contributions OF a Conceptual Pebble Mine to the Alaska and United States Economies iv (2013), http://corporate.pebblepartnership.com/files/documents/study.pdf.

112. Geoffrey Y. Parker et al., Pebble Mine: Fish, Minerals, and Testing the Limits of Alaska's "Large Mine Permitting Process", 25 Alaska L. Rev. 1, 37-38 (2008). See also Alaska STAt. ANN. § 38.05.035(e) (West 2007 \& Supp. 2014); 42 U.S.C. § 4321 (2012).

113. Parker et al., supra note 112, at 37-38.

114. Id. at 37 .

115. 40 C.F.R. $\S 1506.10$ (2016).

116. Timothy J. Mullins, The Clean Water Initiatives and the Proper Balance Between the Right to Ballot Initiatives and the Prohibition on Appropriations, 26 AlASKA L. REV. 135, 139-43 (2009). See also About the Foundation, RENEWABLE RESOURCES Found., http://www.renewableresourcesfoundation.org/about-us (last visited Jan. 21, 2017) (noting the Renewable Resources Foundation supports Bristol Bay fisheries); Parker et al., supra note 112, at 17 
mine opponents turned to the U.S. federal government. ${ }^{117}$ Pebble Mine protestors tried to certify the first Clean Water Initiative in early $2007 .{ }^{118}$ Alaska's Attorney General rejected it, stating it was an appropriation, interfering with the legislature's "power to allocate [various types of] resources amongst competing uses." "119 This way, the Attorney General rejected additional regulations. ${ }^{120}$ A second Clean Water Initiative met a similar fate. ${ }^{121}$ Finally, a third Clean Water Initiative was sent to the Lieutenant Governor in October 2007, and was certified because it only disallowed harmful discharge of waste and pollutants instead of all waste or pollutants. ${ }^{122}$ Section 404(c) of the Clean Water Act grants authority to "the EPA to veto the disposal of dredged material or to put fill in waterways like the major rivers downstream ...."123 "[The] EPA can use the veto authority if it decides that waste disposal into a particular waterway will cause too much harm to aquatic life, recreational areas or drinking water." 124 The Alaska Supreme Court ruled a local ordinance banning large-scale mining activities that would hurt the environment was not enforceable. ${ }^{125}$ This discretionary power of the EPA provided a legal mechanism to challenge the environmental and biodiversity threats of the Pebble Mine proposal. While the desired outcome has been achieved temporarily for environmental protection, the greater problem

(noting former Alaskan governor Jay Hammond's concerns about the Pebble Mine's impacts on Bristol Bay).

117. Kimberley A. Strassel, The Greens' Back Door at the EPA, Wall StREeT J. (May 14, 2015), http://www.wsj.com/articles/the-greens-back-door-at-the-epa-1431645574. See also Margaret Bauman, Pebble Backers Say Fish Refuge Bill Actually Targets Mine, Alaska J. CoM., http://www.alaskajournal.com/community/2007-02-25/pebble-backers-say-fish-refuge-bill-actuallytargets-mine\#.V_BCXVeMDeQ (last updated Feb. 24, 2007). See S. Res. 67, 25th Leg., 1st Sess. (Alaska 2007); H.R. Res. 134, 25th Leg., 1st Sess. (Alaska 2007).

118. See Op. Alaska Att'y Gen., Review of 07WATR Initiative Application, 663-07-0179, 2007 Alas. AG LEXIS 10, at *1 (June 21, 2007).

119. Id. at $* 28-35$ (describing interference with legislature's power of allocating water, watershed, and land resources).

120. Id. at *37.

121. Op. Alaska Att'y Gen., Review of 07WTR2 Initiative Application, 663-07-0179, 2007 Alas. AG LEXIS 25, at *8-36 (Sept. 27, 2007) (rejecting a second Clean Water Initiative application because it impermissibly allocated public assets).

122. Op. Alaska Att'y Gen., Review of 07WTR3 Initiative Application, 663-07-0179, 2007 Alas. AG LEXIS 26, at*30-31 (Oct. 17, 2007); Elizabeth Bluemink, EPA Includes Pebble in Review of Proposed Bristol Bay Projects, Alaska Dispatch News (Feb. 7, 2011), http://www.adn.com/article/20110207/epa-includes-pebble-review-proposed-bristol-bay-projects.

123. Bluemink, supra note 122. See also Rita Ann Cicero, Alaska Supreme Court Rejects Local Law Regulating Large-Scale Mining Activities, 36 WeSTLAw J. ENVTL. 5, 1-2 (2015) (discussing a ruling in which the Alaska Supreme Court determined a local ordinance that banned large-scale mining that would hurt the environment unconstitutional).

124. Bluemink, supra note 122.

125. Jacko v. State, 353 P.3d 337, 338, 346 (Alaska 2015). 
is the steep path to blocking the permitting process. Three separate attempts were made at the state level before the EPA stepped in on the federal level to ensure the environmental protection.

\section{Future Permitting and Review Processes}

The battle over Pebble Mine "has not been won (as some believe)." 126 "Relying on sound science and with massive public support in Alaska and around the nation, the [EPA] proposed a set of commonsense restrictions in July 2014 that could protect Bristol Bay and its incomparable wild salmon fishery from dangerous large-scale mines such as the proposed Pebble Mine." 127 The "EPA is currently prohibited from completing its Bristol Bay work under the Clean Water Act until one of Pebble's various lawsuits is" determined. ${ }^{128}$

The Pebble Mine review process was the first time since the Clean Water Act that the EPA exercised its authority without a permit application. ${ }^{129}$ Mine proponents argue that special interest groups urged the Obama administration to ignore NEPA and rush a decision on a copper mine in Alaska in an attempt to "subvert and evade NEPA."130 Arguments in favor of the mine fail to see how the weakness of the rule being justified on the basis of the Clean Water Act review instead of NEPA is inconsequential because the outcome under NEPA or Clean Water Act would be the same. The phenomenon of the baseline bar was evident based on the conglomeration of scientific environmental expertise. Salmon is "the lifeblood of the region, supporting valuable fish-related economic activity ( $\$ 1.5$ billion annually and 14,000 jobs), Alaska Native subsistence culture, and a vast array of wildlife."131 Brett Miller questions the water-energy contradictions of the regulatory impact

\footnotetext{
126. Bristol Bay: Pebble Is Not Dead; Backers Pin Hopes on Courts \& Congress, SPORTSMAN's AlLIANCE FOR ALASKA (Feb. 15, 2016), http://www.sportsmansalliance4ak.org/newsletters/2016/021516_news.html.

127. Id.

128. Id.

129. Caroline Simson, EPA Pebble Mine Review Wasn't Fair, Report Suggests, LAw360 (Oct. 6, 2015), http://www.law360.com/articles/711421/epa-pebble-mine-review-wasn-t-fair-reportsuggests.

130. John Shively, Will Team Obama Ignore the Rule of Law and Preemptively Veto Pebble Mine?, FoX News (Aug. 1, 2013), http://www.foxnews.com/opinion/2013/08/01/will-team-obamaignore-rule-law-and-preemptively-veto-pebble-mine.html.

131. Taryn Kiekow Heimer \& Joel Reynolds, The EPA Should Stop the Pebble Mine by Prohibiting or Restricting Discharges Associated with Large-Scale Mining in the Bristol Bay Watershed, NAT. RESOURCES DEF. COUNCIL (Jan. 28, 2015), https://www.nrdc.org/resources/epashould-stop-pebble-mine-prohibiting-or-restricting-discharges-associated-large-scale.
} 
of the Pebble Mine decision on renewable energy's dependence on nonrenewable copper. ${ }^{132}$

In January 2014, the EPA released its Watershed Assessment, a final scientific assessment of the Bristol Bay watershed that examined the results of large-scale mining on fish populations, wildlife, development, and Alaska Native communities. ${ }^{133}$ With even "a best case scenariowithout any leaks or failures-Pebble Mine would destroy up to 94 miles of stream and eliminate up to 5,350 acres of wetlands," and in more dire circumstances, "a tailings dam failure would be "catastrophically damaging' to the ecosystem and fisheries."134 In December 2014, President Obama barred offshore oil and gas exploration and development activities in Bristol Bay, calling it "one of Alaska's most powerful economic engines and one of America's greatest national treasures" that is "too special and too valuable to auction off to the highest bidder." 135 Meanwhile, large-scale mining persists in the headwaters of the Bristol Bay watershed. ${ }^{136}$ The size of the Pebble Mine's deposit and its remote location would leave an "immitigable footprint" on account of the mining enterprise. ${ }^{137}$

"Alaska Native tribes, commercial and sport fishing operations, environmental groups and others have all called on the EPA to protect Bristol Bay by issuing a final determination under Section 404(c) of the Clean Water Act." 138 The EPA's mandate under $\S 404$ (c) is broadly defined to prohibit, deny, restrict, or withdraw dredge and fill projects "whenever" the agency determines a reasonable likelihood of "unacceptable adverse effect on municipal water supplies, shellfish beds and fishery areas (including spawning and breeding areas), wildlife, or

132. Brett A. Miller, Embracing the Water-Energy Contradiction: The Pebble Mine Conflict and Regulatory Implications Associated with Renewable Energy's Dependence on Non-Renewable Copper, 19 U. DenV. WATER L. Rev. 213, 237-38 (2016). Environmental implications of the Pebble Mine are a possible indirect consequence of renewable energy's demand for copper, which creates a false choice between salmon and renewable energy. Id. at 234.

133. An Assessment of Potential Mining Impacts on Salmon Ecosystems of Bristol Bay, Alaska (Final Report), EPA, https://cfpub.epa.gov/ncea/bristolbay/recordisplay.cfm?deid=253500 (last updated Oct. 12, 2016).

134. Heimer \& Reynolds, supra note 131.

135. Tanya Somanader, 5 Things You Need to Know About Alaska's Bristol Bay, WHITE House (Dec. 16, 2014), https://www.whitehouse.gov/blog/2014/12/16/5-things-you-need-know-aboutalaskas-bristol-bay (quoting President Barack Obama in the latter quote).

136. Heimer \& Reynolds, supra note 131.

137. Id.

138. The EPA Should Stop the Pebble Mine by Prohibiting or Restricting Discharges Associated with Large-Scale Mining in the Bristol Bay Watershed, NAT. RESOURCES DEF. COUNCIL 2 (Jan. 2015), https://www.nrdc.org/sites/default/files/mining-discharges-bristol-bay-FS.pdf; § 404(c) of the Clean Water Act, 33 U.S.C. § 1344(c) (2012). 
recreational areas."139 The basis of the proposed determination was effects of fishery areas from construction and routine operation of Pebble Mine; loss of anadromous fish streams; loss of tributaries, wetlands, lakes, and ponds; and the downstream flow alteration. ${ }^{140}$ Mine tailings would most dramatically impact the water quality in the region, but impacts to land, air, and terrestrial animals would also be significant. ${ }^{141}$ The EPA's action did not sidestep NEPA, but worked in harmony with the Clean Water Act and existing federal guidelines. Whether a project is thwarted due to NEPA litigation or permitting process is a matter of due process, but having a Clean Water Act determination does not undermine the NEPA processes, instead it complements them.

\section{B. The Social Baseline: Costs, Caveats, and Complaints}

\section{Considering the Keystone XL Pipeline and Free, Prior, and Informed} Consent

The acrimonious contests involving the Keystone XL Pipeline and the Pebble Mine project impacted rights of American Indians to their land. American Indian tribes were at the forefront of both efforts to thwart the projects. An analysis of the baseline bar accounts for formulations of social metrics. The rights of indigenous groups should be factored into determination decisions on the permitting process. ${ }^{142}$ This subsection will look at the interplay between the rights of stakeholders in project development, focusing on indigenous populations. I argue that the "no action" alternative of NEPA should address concerns of indigenous populations, not only with respect to

139. 33 U.S.C. § 1344(c) (2012); EnVtL. Protection Agency, Proposed Determination OF the U.S. ENVIRONMENTAL PRoteCtion Agency REgion 10 Pursuant to SeCtion 404(C) OF the Clean Water Act Pebble Deposit Area, Southwest Alaska 4-1 (July 2014), https://www.epa.gov/sites/production/files/2014-07/documents/pebble_pd_071714_final.pdf.

140. Id. at 4-1 to 4-57.

141. See Bristol Bay's Wild Salmon Ecosystems and the Pebble Mine: Key Considerations for a Large-Scale Mine Proposal, WILD SALMON CTR., https://www.wildsalmoncenter.org/resources/pebble-mine-report-main-page/ (last visited Jan. 21, 2017) (explaining the various economic, ecological and cultural threats found by the Wild Salmon Center and Trout Unlimited in a report examining the potential effects of the proposed Pebble Mine on Bristol Bay).

142. See Uma Outka, Environmental Justice Issues in Sustainable Development: Environmental Justice in the Renewable Energy Transition, 19 J. ENVTL. \& SUSTAINABILITY L. 60, 77-85 (2012); Judith V. Royster, Tribal Energy Development: Renewables and the Problem of the Current Statutory Structures, 31 STAN. ENVTL. L.J. 91, 103-12 (2012); Christy McCann, Dammed If You Do, Damned If You Don't: FERC's Tribal Consultation Requirement and the Hydropower ReLicensing at Post Falls Dam, 41 GoNZ. L. REv. 411, 414-33 (2006). 
environmental impacts and land use, but should more fully account for cultural heritage and stakeholder consent. "When TransCanada filed its application to expand its cross-border oil pipeline operations in the fall of 2008 , it triggered a unique federal approval process and a national dialogue on climate and energy policy."

A Joint Policy Statement on Principles and Guidelines on Indigenous and Traditional Peoples and Protected Areas stated their "rights should be respected in relation to the lands, territories, waters, coastal seas and other resources which they traditionally own or otherwise occupy or use, and which fall within protected areas." 144 Owen Lynch asserts:

The broadening concept of international environmental justice and conservation and duties to promote and protect it reflects an ever more globally acknowledged basic moral principle: human beings, including those belonging to indigenous and other local communities, have a basic human right to participate effectively in official decision-making processes that directly impact the natural resources they depend on for life and livelihoods.

International environmental law norms are implicated in the pipeline siting cases, including in the United States, which historically has sought to ignore international law. ${ }^{146}$ The doctrine of free, prior, and informed consent (FPIC) is crucial in the context of energy siting. ${ }^{147}$ Indigenous

143. Sam Kalen, Thirst for Oil and the Keystone XL Pipeline, 46 Creighton L. Rev. 1, 2-3 (2012).

144. World CONSERVATION Union, World COMM'N ON PROTECTED AREAS, World Wide Fund For NATURE, PRINCIPLES AND GUIDELINES ON INDIGENOUS AND TRADITIONAL PEOPLES AND $\begin{array}{llll}\text { PROTECTED AREAS } & 6 & \text { (1999), }\end{array}$ https://www.iucn.org/sites/dev/files/import/downloads/sp_guidelinesindpeoples.doc; see also Gen. Assembly, UN Declaration on the Rights of Indigenous Peoples, AusTL. Hum. RTS. COMMISSION, https://www.humanrights.gov.au/publications/un-declaration-rights-indigenous-peoples-1 (last visited Jan. 21, 2017).

145. Owen J. Lynch, Mandating Recognition: International Law and Native/Aboriginal Title, 1 PHIL. L. \& $\quad$ SOC'Y REV. $31, \quad 40$ (2011), https://www.academia.edu/4297936/The_Judicial_Review_of_Constitutional_Amendments_The_In surance_Theory_in_Post-Marcos_Philippines; see also OFFICE OF THE HIGH COMM'R FOR HUMAN Rights, Human Rights Ré- ${ }^{-}$. CORPORATIONS AND OTHER BUSINESS ENTERPRISES 1-3 (Apr. 20, 2005), http:// ap.ohchr.org/documents/E/CHR/resolutions/E-CN_4-RES-2005-69.doc (describing the responsibilities of transnational corporations and enterprises with respect to human rights of indigenous populations).

146. See, e.g., Mary \& Carrie Dann v. United States, No. 11.140, Inter-Am. Comm'n H.R. Rep. 75/02 (2003) (the case of Mary \& Carrie Dann v. United States was brought before the InterAmerican Commission of Human Rights); see also James Anaya, Indigenous Peoples' Participatory Rights in Relation to Decisions About Natural Resource Extraction: The More Fundamental Issue of What Rights Indigenous Peoples Have in Lands and Resources, 22 ARIZ. J. INT'L \& COMP. L. 7, 15 n.31 (2005).

147. See Brant McGee, The Community Referendum: Participatory Democracy and the Right to 
people's FPIC right has gained traction in the area of international human rights and the Convention on Biological Diversity. ${ }^{148}$ International standards lean toward consultation of the affected peoples when any development project is either within their lands and territories or that affects traditionally used resources. ${ }^{149}$

The Keystone XL Pipeline consists of two legs. First, a southern leg, which went into operation in 2014, connecting "Cushing, Oklahoma, where there is a current bottleneck of oil, with the Gulf Coast of Texas, where oil refineries abound." 150 Second, the pipeline would include a new section from Alberta to Kansas. ${ }^{151}$ This second portion was the subject of dispute. The President of the Rosebud Sioux Indian Tribe threatened that his tribe will close its reservation borders to the Keystone XL Pipeline, describing authorization of any permit of the pipeline as "an act of war against our people." "152 Whether the Rosebud Sioux Tribe in

Free, Prior and Informed Consent to Development, 27 Berkeley J. InT'L L. 570, 571 n.2 (2009) (quoting Comm'n on Human Rights, Sub-Comm'n on the Promotion and Prot. of Human Rights, Working Group on Indigenous Populations, Legal Commentary on the Concept of Free, Prior and Informed Consent, I 3, U.N. Doc. E/CN.4/Sub.2/AC.4/2005/WP.1 (July 14, 2005)). The U.N. Working Group on Indigenous Populations stated:

The principle of Free, Prior and Informed Consent (FPIC) of indigenous peoples to policies, programs, projects and procedures affecting their rights and welfare is being discussed in a growing number of international, regional, and national processes. These processes cover a wide range of bodies and sectors ranging from the safeguard policies of the multilateral development banks and international financial institutions; practices of extractive industries; water and energy development; natural resources management; access to genetic resources and associated traditional knowledge and benefit-sharing arrangements; scientific and medical research; and indigenous cultural heritage.

Id. See also Anne Perrault, Kirk Herbertson \& Owen J. Lynch, Partnerships for Success in Protected Areas: The Public Interest and Local Community Rights to Prior Informed Consent (PIC), 19 Geo. InT'L ENVTL. L. ReV. 475, 491-92, 497 (2007) (explaining the articulation of prior informed consent (PIC) that most states are likely willing to recognize with respect "to indigenous peoples' self-determination and the right to PIC").

148. Fergus MacKay, Indigenous Peoples' Right to Free, Prior, and Informed Consent and the World Bank's Extractive Industries Review, 4 Sustainable Dev. L. \& POL'y 43, 43 (2004). Regarding the use of traditional knowledge, resettlement and development affecting indigenous lands, the law states that indigenous peoples have the right to give or withhold consent. Id. The concept of FPIC has been recognized and accepted by intergovernmental organizations, international bodies, and domestic laws and jurisprudence. Id.

149. See Tara Ward, The Right to Free, Prior, and Informed Consent: Indigenous Peoples' Participation Rights Within International Law, 10 Nw. U. J. INT'L HUM. RTS. 54, 65 (2011).

150. What Is the Keystone XL Pipeline?, STAтEIMPACT, https://stateimpact.npr.org/texas/tag/keystone-xl-pipeline/ (last visited Jan. 7, 2017).

151. Id.; Scott Neuman, U.S. Issues Keystone XL Pipeline Environmental Review, NPR (Jan. 31, 2014), http://www.npr.org/blogs/thetwo-way/2014/01/31/269504401/u-s-issues-keystone-xlpipeline-environmental-review. "The southern leg of the Keystone XL ... ties into the existing Keystone pipeline that already runs to Canada, bringing up to 700,000 barrels of oil a day to refineries in Texas." Id.

152. Mark Hefflinger, Rosebud Sioux Tribe: House Vote in Favor of Keystone XL Pipeline an Act of War, BolD NeB. (Nov. 15, 2014), http://boldnebraska.org/rosebud-sioux-tribe-house-vote-in- 
South Dakota can inevitably prevent the Keystone XL Pipeline or future pipelines from permitting, construction, and operation rests on the environmental impacts of the project. President Barack Obama preempted any further action on the Keystone XL in 2015. ${ }^{153}$ While TransCanada Corp. does not plan "for the pipeline to cross any tribal land, some [American Indians] fear the project could infringe on their rights." "Various executive orders, laws and treaties require federal officials to consult with [American Indian] tribes about decisions that could affect them." 155 Despite the tribal trust responsibility, the federal government has a poor record of tribal consultation, which effectively denies American Indians "their right to make decisions that affect their land." $" 156$

The issues involved with the Keystone XL Pipeline have not achieved a final resolution as TransCanada Corp. can reapply for the permit and is in the process of litigation against the federal government based on claims of violations arising from the North American Free Trade Agreement (NAFTA) and the constitutionality of the President's actions. TransCanada Corp. filed suit against the U.S. government "to reverse President Barack Obama's rejection of the Keystone XL pipeline,

favor-of-keystone-xl-pipeline-an-act-of-war/.

153. Elise Labbot \& Dan Berman, Obama Rejects Keystone XL Pipeline, http://www.cnn.com/2015/11/06/politics/keystone-xl-pipeline-decision-rejection-kerry/ (last updated Nov. 6, 2015).

154. Timothy Cama \& Megan R. Wilson, Tribes Say No to Keystone, HiLl (Apr. 14, 2015), http://hehill.com/policy/energy-environment/238691-tribes-say-no-to-keystone.

155. Id. The article stated:

"The tribes in the Great Plains are very concerned with what [effect] the Keystone XL project could have on their treaties [with the U.S. government] and their water rights," said John Dossett, the general counsel of the National Congress of American Indians.

Tribes could have legitimate concerns with Keystone over its impacts on aquifers and the potential for oil spills, Dossett said.

TransCanada said it sharply disagrees with the tribes' concerns about spills. Id.

156. Andrea Giampoli, Note, The "New Beginning": Private Cause of Action Under the International Oil Pipeline Permitting System, 14 RUTGERS RACE \& L. REV. 155, 174-78 (2013); see also Judith V. Royster, Environmental Protection and Native American Rights: Controlling Land Use Through Environmental Regulation, 1 KAN. J.L. \& PUB. POL'Y 89, 90-91 (1991) (explaining the effects of the 1887 General Allotment Act on American Indian land and the increased limitations placed on the Indian nations' sovereignty resulting in American Indian nations having "less than full sovereign powers" over resources and land); Robert T. Anderson, Indian Water Rights and the Federal Trust Responsibility, 46 NAT. RESOURCES J. 399, 432-33 n.212 (2006) ("The [Endangered Species Act] can sometimes limit a tribe's exercise of its reserved water rights when tribal use is dependent on federal actions that require section 7 consultations under the Act."); Robert N. Clinton, Redressing the Legacy of Conquest: A Vision Quest for a Decolonized Federal Indian Law, 46 ARK. L. REV. 77, 158-59 (1993) (discussing how Federal Indian Law sometimes protects American Indians, but is rooted in colonialism that enables the federal government to have oversight over and control Indian land instead of providing consultation and negotiations over the land). 
and also plans to seek $\$ 15$ billion in damages from a trade tribunal."157 TransCanada Corp. "called rejection of its permit to build the pipeline unconstitutional.". 158

In reanalyzing the pipeline application, NEPA is sufficient as a legal mechanism to deny the project. What would strengthen NEPA would be consideration of social impacts of the project in the discussion of the "no action" alternative. Social, cultural, and spiritual impacts to indigenous groups and others are quite a bit imprecise to measure. NEPA's establishment of a comprehensive environmental review process for all major federal actions reflects the self-evident principle that compliance must precede actual implementation of any action. "NEPA procedures must insure that environmental information is available to public officials and citizens before decisions are made and before actions are taken." "159 The statute also requires discussion of, "any irreversible and irretrievable commitments of resources which would be involved in the proposed action should it be implemented," "ino_indicating Congress's intent that full environmental review occur before a decision to act is made and, of course, before the action itself is implemented. Courts have adopted this phrase- - "irreversible and irretrievable commitment of resources"- to strike down attempts to comply with NEPA that come only after the agency has already made such a commitment. ${ }^{161}$ Supreme Court precedent, however, indicates that preliminary injunctive relief should not be automatically granted on a presumption of irreparable harm in environmental cases. ${ }^{162}$ Parties alleging violations of NEPA must be prepared to seek injunctions or stays pending appeal of adverse rulings. Failure to obtain an injunction or stay may allow the disputed

157. Nia Williams \& Valerie Volcovici, TransCanada Sues U.S. over Keystone XL Pipeline Rejection, REUTERS (Jan. 6, 2016), http://www.reuters.com/article/us-transcanada-keystoneidUSKBNOUK2JG20160107.

158. Id.

159. 40 C.F.R. $\S 1500.1$ (b) (2016) (emphasis added).

160. 42 U.S.C. $\$ 4332(2)(C)(v)(2012)$.

161. See Metcalf v. Daley, 214 F.3d 1135, 1143 (9th Cir. 2000) (finding the Federal Defendants failed to "engage the NEPA process "at the earliest possible time" and did not consider potential environmental impacts of an action until after an "irreversible and irretrievable commitment of resources").

162. See Amoco Prod. Co. v. Vill. of Gambell, 480 U.S. 531, 544-46 (1987) (finding the Ninth Circuit erred in directing the issuance of a preliminary injunction when environmental injury to subsistence resources was "not at all probable" and oil company petitioners could not recover $\$ 70$ million committed to exploration if enjoined). "[T] NEPA is eradicated if a federal agency makes a decision without proper consideration of the environmental impacts of the proposed project." W. N.C. All. v. N.C. Dep't of Transp., 312 F. Supp. 2d 765, 769 (E.D.N.C. 2003) (citing Sierra Club v. Marsh, 872 F.2d 497, 500 (1st Cir. 1989)). 
action to proceed to completion, thereby mooting the underlying challenge. ${ }^{163}$

\section{Flint and the Public Health Imperative}

Water infrastructure projects may trigger NEPA review. Millions of people are trapped in toxic environments and have more acute environmental and health impacts. Not all Americans have the same access to clean air, clean water, clean parks and recreation areas, and safe workplaces. People of color are trapped in hazardous and toxic environments. ${ }^{164}$ The water crisis in Flint, Michigan, is not only a deviation from environmental standards, but a culmination of poor governance and regulatory frameworks. ${ }^{165}$ Health officials have said "all kids under the age of 6 should be treated with some kind of prevention actions." "F6 Flint Mayor Karen Weaver estimated "that the cost to fix or replace the city's water pipes has been estimated in a range of millions of dollars to up to $\$ 1.5$ billion ....."167

Water contamination involving lead pipes in Flint, Michigan, has led to a number of private lawsuits. ${ }^{168}$ Lawsuits have been filed based on "federal environmental laws, including the Safe Drinking Water Act, and negligence."169 "Earlier lawsuits accused local and state officials of reckless behavior" based on violations of constitutional rights and federal laws. ${ }^{170}$ Other lawsuits sought compensatory damages "for water

163. See One Thousand Friends of Iowa v. Mineta, 364 F.3d 890, 893-94 (8th Cir. 2004) (holding that a NEPA claim was moot because the completion of construction projects prevented the existence of a case or controversy for the court to resolve).

164. Supra notes $12-14$ and accompanying text.

165. See id.

166. Kristi Tanner, All Flint's Children Must Be Treated as Exposed to Lead, Detroit FreE PRESS (Jan. 16, 2016), http://www.freep.com/story/opinion/contributors/raw-data/2016/01/16/map8657-flints-youngest-children-exposed-lead/78818888/. According to Eden Wells, Michigan's chief medical executive, all children who drank Flint's water since April 2014 have been exposed to lead. Id. "It is important when we think about a public health perspective that we consider the whole cohort ... exposed to the drinking water, especially 6 years and under since April 2014, as exposed, regardless of what their blood level is on Jan. 11." Id. (quoting Eden Wells).

167. Ben Klayman, Cost to Fix Flint Water Infrastructure Could Reach $\$ 1.5$ Billion: Reports, REUTERS (Jan. 7, 2016), http://www.reuters.com/article/us-michigan-wateridUSKBNOUL2HW20160107.

168. Veronica Eady \& Nadia Ahmad, Flint: A City in Crisis, ABA SeC. Civ. RTs. \& Soc. JusT. 2

http://www.americanbar.org/content/dam/aba/administrative/crsj/Emails/flintacityincrisis.authcheck dam.pdf.

169. Id.

170. Id. 
payments by water customers and to build a compensation fund."171 This environmental justice crisis has prompted and will continue to prompt new laws to strengthen regulations involving safe drinking water. ${ }^{172}$ Infrastructure updates by water suppliers of more than a quarter-trillion dollars could possibly be expended faster than expected. ${ }^{173}$ At the present, more than six million lead service lines exist all over the United States. ${ }^{174}$

A conceptualization of the baseline bar would raise water quality thresholds for public safety. The baseline bar would also work to decrease toxicity in water, soil, and air. Precise metrics for this formulation would be the purview of the Environmental Protection Agency in coordination with scientists and public health experts. The Flint situation has received the national spotlight, but this type of environmental pollution occurs in communities across the United States, particularly in neighborhoods of people of color and low-income households. Other authorities for establishing a baseline bar for drinking water safety include the Clean Air Act, Federal Water Pollution Control Act, Coastal Barriers Resource Act, Coastal Zone Management Act, Endangered Species Act, Farmland Protection Policy Act, Fish and Wildlife Coordination Act, Floodplain Management Executive Order 11988, National Historic Preservation Act, Protection of Wetlands Executive Order 11990, Wild and Scenic Rivers Act, essential fish habitat consultation process under the Magnuson-Stevens Fishery Conservation and Management Act. ${ }^{175}$ These environmental authorities offer multiple layers of federal regulation to coordinate efforts for environmental protection, public health, and occupational safety as embedded within NEPA compliance for the "no action" alternative. These procedural components of NEPA provide a tool for litigation to stop project development.

171. Id

172. See id. (noting the effects if the EPA changing existing regulations to make them more stringent).

173. Matthew Dolan, U.S. Could Face a $\$ 300 B$ Lead Pipe Overhaul, Agency Warns, Detroit FREE PRESS, http://www.freep.com/story/news/local/michigan/flint-water-crisis/2016/03/04/flintcrisis-could-cost-us-300b-lead-pipe-overhaul-agency-warns/81316860/ (last updated Mar. 5, 2016).

174. Id. Many of the lead pipe service lines "are located in the Northeast, Midwest and older urban areas." Id.

175. Envtl. Planning Program, 69 Fed. Reg. 33043-03 (June 14, 2004) https://www.federalregister.gov/documents/2004/06/14/04-13111/environmental-planning-program; 16 U.S.C. $\S \S 3501-3510$ (2012 \& Supp. III 2015); 7 U.S.C. $\S \S 4201-4209$ (2012); 16 U.S.C. $\S ~$ 661-667d (2012); 16 U.S.C. §§ 1271-1287 (2012 \& Supp. III 2015); 16 U.S.C. § 1855(b) (2012). 


\section{The Economic Baseline: Grazing Fees, Ranchers, and the Oregon Standoff in Perspective}

The Oregon standoff at a federal wildlife reserve spotlighted the natural resource conflict over grazing rights on federally owned land that has been a source of contestation for decades across the West. ${ }^{176}$ This situation also showcases the relevance of the baseline bar conundrum. Ranchers argued that the government's environmental priorities lead to more quarrelsome constraints on grazing, timber harvesting, and mineral extraction on the federally owned lands, which had previously sustained generations of their families. ${ }^{177}$ The ranchers in the view of conservationists "are actually the beneficiaries of a government subsidy that effectively pays them to destroy some of the West's remaining natural treasures by offering grazing land at deeply discounted rates."178 BLM and USFS jointly manage grazing rights, where livestock grazing is permitted on 155 million acres of BLM-managed lands and 95 million acres of U.S. Forest Service lands. ${ }^{179}$ The permits and leases for grazing livestock on these lands are issued for 10 years and can be renewed based on the government's conditions. ${ }^{180}$

Applying the baseline bar standard to federal grazing leases, the economic metrics of the leasing and management of the leasing process makes the grazing of livestock not a lucrative venture for the government. This economic consideration in line with the environmental concerns and social benefits of livestock grazing require a balancing test. To adequately account for the environmental externalities of grazing on public lands, another economic analysis must occur to determine a feasible policy. The BLM's Land Health Standards evaluations consider the health of BLM lands on the basis of Fundamentals of Rangeland

176. Alexandra Zavis, Oregon Standoff: Who's Really Getting Hurt by Federal Grazing Laws?, L.A. Times (Jan. 6, 2016), http://www.latimes.com/nation/la-na-oregon-standoff-federal-grazinglaws-20160106-story.html.

177. Id. "'All of that makes the ranchers feel like they are under siege, and they push back,' said John Freemuth, a professor of public policy at Boise State University in Idaho." Id.

178. Id.

179. Fact Sheet on the BLM's Management of Livestock Grazing, U.S DEP'T INTERIOR BUREAU LAND MGMT., http://www.blm.gov/wo/st/en/prog/grazing.html (last updated Oct. 21, 2016) (noting the existence of 155 million acres of BLM-managed lands); Alexandra Zavis, Grazing Rights at Center of Oregon Standoff, GREELEY TRIB. (Jan. 8, 2016), $\mathrm{http} / /$ www.greeleytribune.com/news/local/grazing-rights-at-center-of-oregon-standoff/ (noting the existence of 95 million acres of U.S. Forest Service lands).

180. Zavis, supra note 179. See also The Taylor Grazing Act, U.S DEP'T INTERIOR BUREAU LAND MGMT., http://www.blm.gov/wy/st/en/field_offices/Casper/range/taylor.1.html (last updated Jan. 13, 2011). 
Health. ${ }^{181}$ BLM addresses whether allotments satisfying the standards, are failing, and if failing, whether livestock grazing is a significant cause, or failing to meet standards based on other factors. ${ }^{182}$ The Public Employees for Environmental Responsibility sued BLM, alleging that the Interior Department employees blocked the use of federal data for regional scientific studies. ${ }^{183}$

The final section examines why projects should be thwarted due to climate change concerns and broader environmental impacts and reconciles the "no action" alternative of the EIS with the push for sustainability, trade, and economic empowerment. The interplay between science, technology, and society (STS) provides a backdrop for the discussion on the use of data for benchmark metrics for the baseline bar.

\section{ReCONCILING THE “No ACtiON” Alternative AND PROJECT REJECTION}

The law has failed to adequately consider the environment in its rulemaking and governance decisions despite advances in science and environmental monitoring. The environment is an afterthought instead of at the forefront of rulemaking, project management, and design. This trend to neglect the environment along with social impacts is ironically most evident in energy policy, even in the case of renewables.

181. About the BLM Grazing Data, PuB. EMPS. ENVTL. RESP., http://www.peer.org/campaigns/public-lands/public-lands-grazing-reform/blm-grazing-data.html (last visited Jan. 21, 2017). These standards are defined in 43 C.F.R. $§ 4180.1$ (2016) and include the following information:

$[P]$ roperly functioning watersheds (the condition of soils and vegetation, which impact water filtration and water quality), maintenance of ecological processes (how the hydrologic cycle, nutrient cycle, and energy flow are maintained) to support healthy biotic populations and communities, maintenance of the quality of surface waters, and maintenance of habitats for native plant and animal communities and listed or at-risk species.

182. About the BLM Grazing Data, supra note 181.

183. Felicity Barringer, The Impact of Grazing? Don't Ask, N.Y. TIMES (Dec. 1, 2011), http://green.blogs.nytimes.com/2011/12/01/the-impact-of-grazing-dont-ask/?_r=0. Public Employees for Environmental Responsibility filed a complaint stating that actions by government workers "seriously compromise' the scientific integrity of efforts" to determine the actual and proximate causes of changes to the western ecosystems. Id. The plaintiffs claimed that BLM employees not only inhibited ecosystem scientists from including grazing as part of their study but also failed to let them know of existing data. Id. Therefore, the discrete impact caused by livestock is ignored by BLM in addressing the checklist of man-made and natural forces that could lead to "erosion, lower water quality or cause the extinction of plants or animals ...." Id. 


\section{A. Normative Implications of the Baseline Bar}

NEPA forbids an environmental review process that is manipulated to support a predetermined, favored outcome. There are abundant NEPA provisions and cases confirming that agencies must hold themselves to the highest standards of objectivity, candor, analytical rigor, and cooperation with the public and fellow agencies. Environmental information generated by NEPA "must be of high quality" and "[a]ccurate scientific analysis... [is] essential to implementing NEPA."184 EISs "shall be supported by evidence that agencies have made the necessary environmental analyses." 185 In addition, EISs "shall be analytic rather than encyclopedic." 186 More specific information for environmental, social, and economic metrics would not only have to be included in the "no action" alternative section of the EIS, but that information would also be subject to deeper scrutiny. "NEPA is the national equivalent of a land-use planning mandate," "and as such, its strengths are gathering and analyzing information relevant to decisionmakers ...."187 In a review of social, cultural, and economic impact assessments for the EPA, Galisteo Consulting Group noted "that this impact criterion lacks methodological rigor and sufficient guidance." Analysts for EISs and EAs do not know how to prepare and interpret data, "other than to dichotomize the impacts as significant or not," which leads to the preparation of a safe report. ${ }^{189}$ These types of reports may satisfy the regulatory requirements, but these reports do not benefit the communities and natural ecosystems, which the EPA seeks to protect. If the EIS and EA does not more fully and adequately account for environmental justice as well as socioeconomic considerations, it fails to be comprehensive.

"Judicial review of agencies' compliance with the NEPA reveals that courts assume a very limited role when assessing the adequacy of an agency's analysis of disproportionate social or economic impacts from a proposed action." 190 Courts are deferential to the agencies' analysis "of

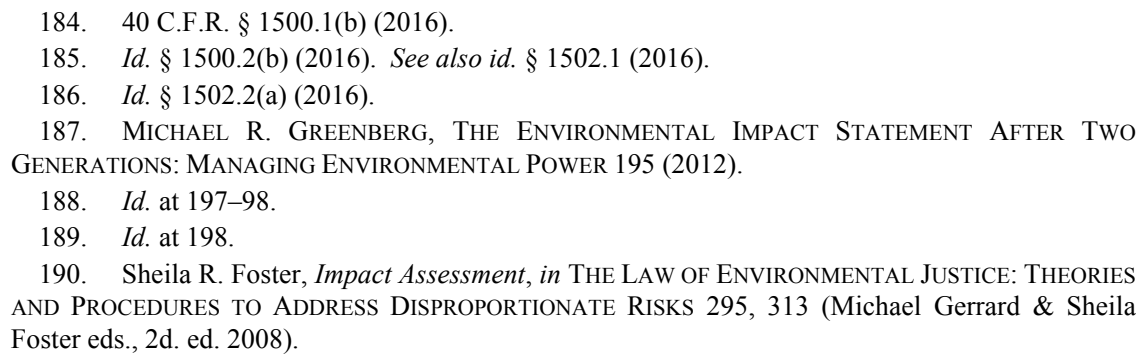

190. Sheila R. Foster, Impact Assessment, in THE LAW OF ENVIRONMENTAL JUSTICE: THEORIES AND PROCEDURES TO ADDRESS DisProportionate Risks 295, 313 (Michael Gerrard \& Sheila Foster eds., 2d. ed. 2008). 
the geographic scope of impact assessment, the measurement of cumulative or indirect impacts, and the range of alternatives considered." "191 Overall, determining the effectiveness of NEPA is complicated. The EIS could serve as a post hoc rationalization-simply going through the bureaucratic motions. ${ }^{192}$ James Salzman and Barton Thompson, Jr., note, "Placing agencies in charge of conducting an EIS that may challenge their proposed actions ... is like placing the fox as guard of the hen house." $" 193$ Based on these constraints of the NEPA process, public citizens have taken the route of litigation to address environmental grievances. One such type of lawsuit that is gaining traction is atmospheric trust litigation. The next subsection explains the rise of atmospheric trust litigation.

\section{B. Atmospheric Trust Litigation}

"When environmental law works, and the agencies actually implement the laws, there should be no need for judicial intervention. But right now the agencies have turned these statutes inside out. Across the board on the state, local, and federal level, the agencies are not using the statutes to protect nature - they're using statutes to permit damage to the environment. These statutes have turned into broad permitting systems, and permit denials have been the exception. That's why we see cascading collapses of resources, because the environmental laws simply aren't working. And the sooner the public realizes that, the sooner we can hold our agencies accountable."

\section{Mary Christina Wood ${ }^{194}$}

Atmospheric trust litigation "reasons that a government elected by the people has a duty to protect the natural systems required for their survival." ${ }^{195}$ The legal framework relies on the public trust doctrine to

191. Id. See Cmtys. Against Runway Expansion, Inc. v. Fed. Aviation Admin., 355 F.3d 678, 689 (D.C. Cir. 2004); Senville v. Peters, 327 F. Supp. 2d 335, 367 (D. Vt. 2004).

192. JAMES SALZMAN \& BARTON H. THOMPSON, JR., ENVIRONMENTAL LAW AND POLICY 34748 (4th ed. 2014).

193. Id. at 347.

194. Fen Montaigne, A Legal Call to Arms to Remedy Environmental and Climate Ills, YALE $\begin{array}{lllll}\text { ENV'T } & 360 & \text { (Jan. 2014), }\end{array}$ http://e360.yale.edu/feature/interview_mary_wood_a_legal_call_to_arms_to_fix_environmental_and _climate_ills/2724/ (interviewing University of Oregon law professor Mary Christina Wood).

195. James Conca, Atmospheric Trust Litigation-Can We Sue Ourselves over Climate Change?, Forbes (Nov. 23, http://www.forbes.com/sites/jamesconca/2014/11/23/atmospheric-trust-litigation-can-we-sueourselves-over-climate-change/\#40ef4b6f2317.

"Equity between generations is a key issue with climate change," said Ross Macfarlane, Senior Advisor with Climate Solutions, a Northwest based clean economy organization 
define government responsibility in climate crisis and impose a fundamental limitation on the power of government over natural resources. ${ }^{196}$ Government maintains natural resources in trust for its citizens and carries the fiduciary obligation to protect these resources for present and future generations. ${ }^{197}$ The trust is embedded in the law as an attribute of sovereignty itself. ${ }^{198}$

The public trust is a common law doctrine that conserves navigable waters and tidal lands for public use, and institutes a duty in governments to guard such public use. ${ }^{199}$ "[M] ost American PTD common law has concerned tidal areas, navigable waters, and submerged lands."200 PTD expansion has found imperfect legal victories. Although past rulings applied the PTD to federal lands, more recent decisions have found it inapplicable to federal lands. ${ }^{201}$ Some scholars have argued that judicial restraint, rather than an inherent limitation of the PTD to state-controlled resources, is responsible for the lack of application of the PTD to federal resources. ${ }^{202}$ While the future of atmospheric trust litigation is uncertain, it has been supported by an innovative legal strategy through the Oregonbased organization, Our Children's Trust. ${ }^{203}$ The organization has

\footnotetext{
which has also participated in these lawsuits. "Those who benefit most from the carbon pollution won't be around to feel the worst impacts. These actions attempt to redress that Id. balance, and allow future generations a voice in the legal system."

196. Mary Christina Wood, Atmospheric Trust Litigation Across the World, in FIDUCIARY Duty AND THE ATMOSPHeric TRUST 99, 106 (Ken Coghill, Charles Sampford \& Tim Smith eds. 2012). For discussion of the public trust doctrine, see Joseph L. Sax, The Public Trust Doctrine in Natural Resource Law: Effective Judicial Intervention, 68 MicH. L. REV. 471, 558-66 (1969), http://scholarship.law.berkeley.edu/facpubs/1359; Harrison C. Dunning, The Public Trust: A Fundamental Doctrine of American Property Law, 19 ENVTL. L. 515 (1989); Mary Christina Wood, Advancing the Sovereign Trust of Government to Safeguard the Environment for Present and Future Generations (Parts I and II), 39 ENVTL. L. 43, 43-139 (2009).

197. Ill. Cent. R.R. v. Illinois, 146 U.S. 387, 455 (1892); Ariz. Ctr. for Law in the Pub. Interest v. Hassell, 837 P.2d 158, 168-69 (Ariz. Ct. App. 1991).

198. Jan S. Stevens, The Public Trust: A Sovereign's Ancient Prerogative Becomes the People's Environmental Right, 14 U.C. DAVIS. L. REV. 195, 196 (1980). An ancient and enduring principle, it has roots and reasoning that put it on par with the highest liberties of citizens living in a free society. Id. at $195-96$.

199. Sax, supra note 196. Public-Trust Doctrine, BlACK's LAW DiCTIONARY (10th ed. 2014) (defining "public-trust doctrine" as "[t]he principle that navigable waters are preserved for the public use, and that the state is responsible for protecting the public's right to the use").

200. Tim Kline, Alec L. and Federal Atmospheric Trust Litigation: Conceptual and Political Gains Amidst Legal Defeat?, 42 Ecology L.Q. 549, 550-53 (2015). See also Ill. Cent. R.R., 146 U.S. at 435 .

201. See, e.g., United States v. 1.58 Acres of Land, 523 F. Supp. 120, 124 (D. Mass. 1981). See also Kline, supra note 200, at 549.

202. Gerald Torres \& Nathan Bellinger, The Public Trust: The Law's DNA, 4 WAKE FOREST J.L. \& POL'Y 281, 295 (2014).

203. Mission Statement, OUR CHILDREN's TRUST, http://www.ourchildrenstrust.org/mission-
} 
launched strategically-placed and youth-driven legal proceedings in federal and state courts and agencies, and in many other countries. ${ }^{204}$ Through this strategy, youth ask their governments to establish enduring protection for our atmosphere through enforceable "science-based climate recovery policies." 205 The United States has served as a frontrunner in environmental protection efforts globally even though it is the largest emitter of carbon emissions after China. The United States has been a party to a number of international instruments, which take environmental degradation into account of natural resource extraction activities.

\section{International Obligations and Eco-efficiency}

"We are the first generation that can end poverty and the last generation that can take steps to avoid the worst impact of climate change. Future generations will judge us harshly if we fail to uphold our moral and historical responsibilities."

U.N. Secretary-General Ban Ki-moon ${ }^{206}$

The United States has worked with the United Nations to strengthen stakeholder rights for a clean environment. Recently, the United States has also negotiated with countries to sign bilateral and multilateral agreements to reduce carbon emissions and encourage the deployment of renewable energy.

During the United Nations Conference on Environment and Development (UNCED), also known as the Earth Summit, in Rio de Janeiro, Brazil, in 1992, the United Nations encouraged governments to "rethink economic development and find ways to halt the destruction of irreplaceable natural resources and pollution of the planet."207 One of the major outcomes of the UNCED was eco-efficiency, which strove for improvements in patterns of production, renewable energy, greater reliance on mass transit, and the concern for diminishing water

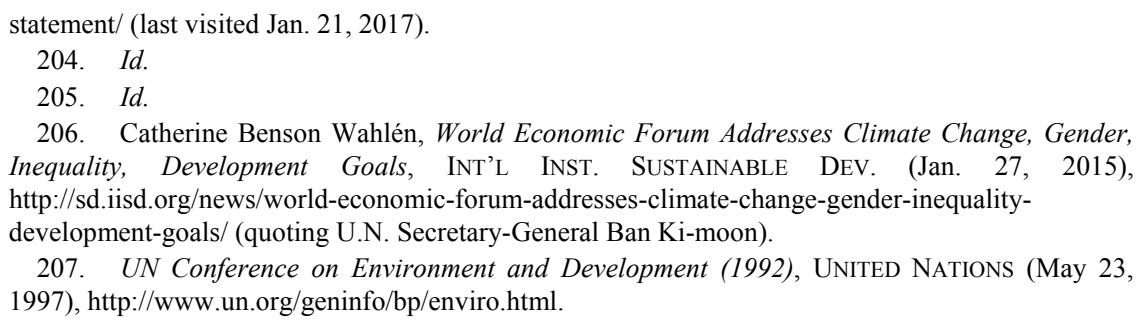


resources. $^{208}$ The UNCED was historic in its scope even though it did not bring major changes to international law or dispute resolution mechanism, it brought "attention on the implementation and 'effectiveness' of existing environmental conventions ...."209 Now twenty-five years later, the Earth Summit serves as a reminder to continue the original call to preserve the planet's scarce natural resources. Principle 12 of the Rio Declaration indicates, "States should cooperate to promote a supportive and open international economic system that would lead to economic growth and sustainable development in all countries, to better address the problems of environmental degradation." 210 Principle 12 also recognizes that trade policy measures for environmental purposes should not be "a means of arbitrary or unjustifiable discrimination or a disguised restriction on international trade." 211 In addition, Principle 12 says that international consensus should be determinative of "[e]nvironmental measures addressing transboundary or global environmental problems...."212 The lofty aspirations of the Rio Declaration are slowly being realized, but not at the rate the drafters intended.

In 1998, the United Nations Economic Commission for Europe (UNECE) Convention on Access to Information, Public Participation in Decision-Making and Access to Justice in Environmental Matters (Aarhus Convention) was adopted as part of the "Environment for Europe" process and became effective in 2001. ${ }^{213}$ The Aarhus Convention established "a number of rights of the public (individuals and their associations) with regard to the environment."214 "The Parties to the [Aarhus] Convention are required to make the necessary provisions so that public authorities (at national, regional or local level) will contribute to these rights" to make them effective. ${ }^{215}$

In 2002, the Johannesburg Plan of Implementation was formulated to carry forth the goals of the UNCED. The Johannesburg Plan of

208. Id.

209. Peter H. Sand, Kaleidoscope: International Environmental Law After Rio, 4 EUROPEAN J. INT'L L. 377, 388 (1993).

210. UNITED NATIONS, REPORT OF THE UNITED NATIONS CONFERENCE ON ENVIRONMENT AND DEVELOPMENT (1992), http://www.un.org/documents/ga/conf151/aconf15126-1annex1.htm.

211. Id. Principle 12 further states, "Unilateral actions to deal with environmental challenges outside the jurisdiction of the importing country should be avoided." Id.

212. Id.

213. Aarhus Convention, EUROPEAN COMMISSION, http://ec.europa.eu/environment/aarhus/ (last updated Dec. 19, 2016).

214. Id.

215. Id. 
Implementation more clearly defined the evolving concept of sustainable development to expedite the realization of the remaining goals of UNCED. ${ }^{216}$ In the United States, the Environmental Law Institute published Stumbling Toward Sustainability, which was a collaboration of the U.S. initiative by 42 contributors from universities, law schools, private law firms and NGOs. ${ }^{217}$ The report realized the significance of maintaining the Earth Summit's commitments and devising a roadmap toward sustainability. ${ }^{218}$ The report recommended a reduction in the "environmental impacts from the production and consumption of materials and energy" and changing current laws so that "natural resources law [] have the same kind of environmental goals and implementing mechanisms as our air and water pollution laws." ${ }^{\text {,19 }}$ Still, the onus for sustainable development lies with the corporations. Especially in the energy industry, the government can serve as guide, but the industry has to be willing to step up instead of shirking social and environmental responsibilities in the hopes of greater economic prosperity.

The United Nations Conference on Sustainable Development in 2012 in Rio de Janeiro, Brazil—known as Rio+20 — was designed "to secure renewed political commitment for sustainable development, assess the progress to date and the remaining gaps in the implementation of the outcomes of the major summits on sustainable development, and address new and emerging challenges." 220 Results of the Rio+20 meeting have been mixed, because it "did not produce any breakthrough agreements or commitments, but it provided an international platform to shed light on pressing issues in the quest to secure global sustainable development."221

In 2015, leaders from nearly every country met in Paris and agreed to a climate change agreement, which was "hailed as 'historic, durable and ambitious." ${ }^{222}$ Developed and developing countries are mandated to

216. United Nations, Johannesburg Declaration on Sustainable Development of Sept. 4, 2002, UN DOCUMENTS (2002), http://www.un-documents.net/jburgdec.htm.

217. John Dernbach \& Ira Feldman, After Johannesburg: Sustainable Development Begins at Home, 12 ENVTL. QuALITY MgMT. 87, 89 (2003).

218. Id.

219. Id.

220. Objectives and Themes, U.N. Division SustainaBle DeV., https://sustainabledevelopment.un.org/rio20/objectivethemes (last visited Jan. 21, 2017).

221. Suan Ee Ong, Rômulo S.R. Sampaio, Andrei Marcu, Agathe Maupin \& Elizabeth Sidiropoulos, Examining Rio+20's Outcome, COUNCIL ForeIGN Rel. (July 5, 2012), http://www.cfr.org/world/examining-rio20s-outcome/p28669.

222. Fiona Harvey, Paris Climate Change Agreement: The World's Greatest Diplomatic Success, GUARDIAN (Dec. 14, 2015), http://www.theguardian.com/environment/2015/dec/13/parisclimate-deal-cop-diplomacy-developing-united-nations. 
reduce emissions to 2 degrees Celsius with a goal of 1.5 degrees Celsius with periodic monitoring. ${ }^{223}$ Even though all of the 2015 Paris Climate Agreement is not binding on the nations, the priority of protecting the planet from climate change was achieved. ${ }^{224}$ The Paris Climate Agreement served primarily to benefit the transnational economic interests that seek to expand green technologies, renewables, and other sustainability projects. The baseline bar would apply internationally as well as domestically to curb carbon emission and limit human-induced climate change. One of the underlying motivations of the baseline bar is to thwart new projects and to limit the amount of new infrastructure development in line with zero growth strategies. The next section will examine the impact of free trade agreements on environmental protection.

\section{Free Trade and the Environment}

Signed by the leaders of 12 nations, including the United States, which withdrew from the agreement on January 23, 2017, the TransPacific Partnership (TPP) is "the largest regional trade agreement in history ...."225 The TPP requires signatories to conform to specific

223. Id. Poor nations will receive finance to reduce emissions and handle problems associated with extreme weather. Id. Aid will be provided to countries impacted by climate disasters. Id.

224. Id. The Guardian reported on the magnitude of the agreement, even if the caps are loose:

Like any international compromise, it is not perfect: the caps on emissions are still too loose, likely to lead to warming of 2.7 to $3 \mathrm{C}$ above pre-industrial levels, breaching the $2 \mathrm{C}$ threshold that scientists say is the limit of safety, beyond which the effects - droughts, floods, heatwaves and sea level rises - are likely to become catastrophic and irreversible. Poor countries are also concerned that the money provided to them will not be nearly enough to protect them. Not all of the agreement is legally binding, so future governments of the signatory countries could yet renege on their commitments.

$\ldots$

It is easy to forget what an extraordinary event these UN talks were. The UNFCCC is one of the last remaining forums in the world where every country, however small, is represented on the same basis and has equal say with the biggest economies. Most modern diplomacy carries on in small, self-selected groups dominated by richer countries - the G7, the G20, the OECD, Opec - but all 196 states have a seat and a say at the UNFCCC. Agreement can only be accepted by consensus.

If this makes for an unwieldy and frustrating process, it is also a fair one. The poorest countries of the world, so often left out of international consideration, are those which have done least to create climate change, but will suffer the most from it. Only at the UN are they heard. Id.

225. Hannah Lewis, UC Berkeley Researchers Raise Corporate Misconduct Concerns Regarding Trans-Pacific Partnership in Report, DAILY CALIFORNIAN (Mar. 10, 2016), http://www.dailycal.org/2016/03/10/uc-berkeley-researchers-raise-corporate-misconduct-concernsregarding-trans-pacific-partnership-report/. Ylan Q. Mui, Withdrawal from Trans-Pacific Partnership Shifts U.S. Role in World Economy, WASH. PosT (Jan. 23, 2017), 
policies, namely financial services, intellectual property, Internet policy, and safety inspections. ${ }^{226}$ President Trump had vowed to withdraw from the TPP once he assumes power. A multilateral agreement would provide "regulatory coherence and good regulatory practices, together with mechanisms ... [to] address non-tariff measures in export markets." 227 He has promised to renegotiate multilateral trade agreements as separate bilateral agreements, which would be "more inefficient and disruptive., 228

The TPP includes provisions that impact environmental decisionmaking, like Article 20.7(5): Procedural Matters of the TPP, provides, that parties "shall provide appropriate sanctions or remedies for violations of its environmental laws for the effective enforcement of those laws" that includes "action directly against the violator to seek damages or injunctive relief, or a right to seek governmental action." "229 Consideration for the type of action taken includes "the nature and gravity of the violation, damage to the environment and any economic benefit the violator derived from the violation." ${ }^{, 30}$ Side effects of these provisions for the environment are ancillary provisions in the TPP for dispute resolution. For disputes involving energy companies, provisions of the TPP could potentially upset more stringent domestic law, particularly in the case of the United States. TPP includes an Investor-State Dispute Settlement (ISDS) provision that "allows corporations to sue foreign governments over environmental or public health regulations" based on

\footnotetext{
https://www.washingtonpost.com/business/economy/withdrawal-from-trans-pacific-partnershipshifts-us-role-in-world-economy/2017/01/23/05720df6-e1a6-11e6-a453-

19ec4b3d09ba_story.html?utm_term $=.0748113 \mathrm{eb} 87 \mathrm{c}$.

226. Id.

227. Harsha Vardhana Singh, How Donald Trump May Re-negotiate the TPP, LiveMINT (Nov. 30, 2016), http://www.livemint.com/Opinion/7GUxCQ3emTlfIOrPCoZw3M/How-Donald-Trumpmay-renegotiate-the-TPP.html.

228. Id. Singh questions the efficacy and impact of switching from multilateral agreements to bilateral agreements:

Each TPP partner will need to enter new bilateral trade negotiations with the US, including those with whom the US already has bilateral or trilateral free trade agreements. This is because the TPP has a number of additional issues, in comparison to the US' existing bilateral trade deals. These include regulatory coherence, state-owned enterprises, small and medium-sized enterprises, temporary entry of businesspersons, competitiveness and business facilitation, development, and cooperation and capacity building. Separate bilateral trade with each TPP partner will be a time-consuming and Id. tedious process that will re-invent significant parts of an existing wheel, i.e. the TPP.

229. U.S. Trade Representative, TPP: Made in America: Chapter 20: Environment, MEDIUM, at art. 20.7(5), https://medium.com/the-trans-pacific-partnership/environmenta7f25cd180cb\#.pa48mefti (last visited Jan. 21, 2017).

230. Id. at art. 20.7(6).
} 
an adverse impact on profits. ${ }^{231}$ The cases on these matters are set before private arbitration panels instead of public courts "to protect foreign investors from unfair or arbitrary treatment by foreign governments," but such a system "favors companies and makes it difficult for governments to enforce regulations."232 For example, since the North American Free Trade Agreement (NAFTA) in 1994, the number of these types of ISDS cases has exploded. ${ }^{233}$

Trade agreements, economist Jeffrey Sachs argues, "establish many important rules of the economy beyond trade" and "give far too much power to large multinational companies, the corporations whose lobbyists have helped to draft the agreements." ${ }^{234}$ The other concern is that trade agreements are drafted away from related budget measures to account for more fair and just economic outcomes. ${ }^{235}$ The ISDS provisions in NAFTA "undermine government regulations and the ability for the public to rein in corporate greed and recklessness." 236

I include this section on free trade agreements to show how NEPA's existing strategy for environmental protection can be further weakened. Whether future trade agreements are bilateral or multilateral in nature, they can diminish the efficacy of environmental regulations. Even though current bureaucratic processes depress NEPA's impact statement strategy, these international trade agreements will remove jurisdiction from domestic courts to alternative dispute resolution that will favor corporations' economic interests instead of the public's environmental concerns. Public-private partnerships could operate to bridge this divide. In the face of mounting economic priorities, I offer the baseline bar as a way for analyzing and assessing baseline metrics for social, environmental and economic interests.

231. Catherine Ho, Fact-Checking the Campaigns for and Against the TPP Trade Deal, WASH. PosT (Feb. 11, 2016), https://www.washingtonpost.com/news/powerpost/wp/2016/02/11/factchecking-the-campaigns-for-and-against-the-tpp-trade-deal/.

232. Id.

233. Id. "That year, two such arbitrations were initiated, and the number has grown since then-reaching a record 70 in 2015, according to the United Nations Conference on Trade and Development." Id. "More than $\$ 400$ million has been paid out to corporations in investor-state cases under NAFTA-style deals ...." Id.

234. Jeffrey D. Sachs, The Truth About Trade, Bos. GloBE (Oct. 17, 2016), https://www.bostonglobe.com/opinion/2016/10/16/the-truth-about-

trade/UWtu8jpAo8LTsTFlffaZ0K/story.html.

235. Id.

236. Michael Sainato, TransCanada Gets to Pick Own Judges in Lawsuit Against US Government, OBSERVER (Sept. 12, 2016), http://observer.com/2016/09/transcanada-gets-to-pickown-judges-in-lawsuit-against-u-s-government/. 


\section{CONCLUSION}

When native American protesters sat down in front of bulldozers to try and protect ancestral graves, they were met with attack dogs- the pictures looked like Birmingham, Alabama, circa 1963. But it went back further than that: the encampment, with its teepees and woodsmoke hovering in the valley, looked like something out of an 1840 s painting. With the exception that this was not just one tribe: this was pretty much all of native North America. The flags of more than 200 Indian nations lined the rough dirt entrance road. Other Americans, drawn in part by a sense of shame at this part of our heritage. flooded in to help-when the announcement came today, there were thousands of military veterans on hand. ${ }^{237}$

The baseline bar is important for a complete and final future of rejecting the already stayed projects involving Alaska's Pebble Mine and the Keystone XL Pipeline. These projects and others face rebirth under new national leadership. President Trump's energy and industry plans seek to limit environmental regulations to expand energy and extractive sectors. $^{238}$ For example, after the halt of the Keystone XL Pipeline, the proposed Dakota Access Pipeline crossing native burial grounds also received significant resistance, leading up to the denial of the U.S. Army Corps of Engineers of a critical easement. ${ }^{239}$ President Trump has vowed to "immediately approve the Keystone XL pipeline" 240 and has provided clearance to finish the Dakota Access Pipeline. ${ }^{241}$ The struggle for achieving sustainable and reliable energy sources and establishing sustainable energy infrastructure will lead to increased conflicts for natural resources in the coming decades. The balancing of natural resource constraints leads to greater land preservation if the baseline bar is configured and actualized. Having a specific, more robust "no action" alternative in the environmental impact assessment will be critical.

In light of the push for more balanced trade agreements and

237. Bill McKibben, The Victory at Standing Rock Could Mark a Turning Point, GUARDIAN (Dec. 4, 2016), https://www.theguardian.com/commentisfree/2016/dec/04/standing-rock-victoryturning-point?CMP=share_btn_tw.

238. O'Reilly, supra note 5.

239. See generally Nadia B. Ahmad, Trust or Bust: Complications with Tribal Trust Obligations and Environmental Sovereignty (2017) (on file with author).

240. O’Reilly, supra note 5. President Donald J. Trump (@realDonaldTrump), TwitTER (Aug. 18, 2015, 1:39 PM) (mentioning "If I am elected President I will immediately approve the Keystone XL pipeline. No impact on environment \& lots of jobs for U.S.").

241. Juliet Eilperin \& Brady Dennis, Trump Administration to Approve Final Permit for Dakota Access Pipeline, WASH. POST (Feb. 7, 2017), https://www.washingtonpost.com/news/energyenvironment/wp/2017/02/07/trump-administration-to-approve-final-permit-for-dakota-accesspipeline/?utm_term=.f65391e94e27. 
resistance to momentum for climate change adaptation and environmental protection in the United States, NEPA's impact statement processes will be tested. NEPA's procedural claims will provide an additional avenue for environmentalist activists to pursue litigation. To counter the surge of commercial activity and environmental degradation, the baseline bar is a way to reject projects and preserve the planet for future generations, the epitome of sustainability. 